\title{
Adaptation of Preservice Teachers' Information and Communication Technology Competencies Scale into Turkish Culture
}

\author{
Muhammet Fatih ALKAN*a, Esma EMMIOĞLU-SARIKAYA ${ }^{b}$
}

\section{Article Info}

DOI: $10.14686 /$ buefad.375745

Article History:

Received: $\quad 06.01 .2018$

Accepted: $\quad 31.05 .2018$

Published: 30.06 .2018

Keywords:

Preservice teachers'

information and

communication technologies

competencies scale,

Teacher education,

Confirmatory factor analysis.

Article Type:

Research Article

\begin{abstract}
The purpose of this study was to adapt Preservice Teachers' ICT Competencies Scale which was developed by Tondeur, Aesaert, Pynoo, Braak, Fraeyman, and Erstad (2017) into Turkish. The participants were composed of 206 preservice teachers studying at Gaziosmanpaşa University during 2017-2018 academic year. The results showed that the Turkish version fits the original two factor structure. The correlation coefficients between the data obtained from the Turkish version and the data obtained from General ICT Tendency, Reality Shock Expectation, and Prospective Teachers' Perceived Competencies about Integrating ICT into Education were examined to test convergent, divergent and concurrent validity. The results indicated that the data obtained from the Turkish version of the scale were valid. Moreover, the Cronbach alpha coefficients indicated that the data were internally consistent. In conclusion, the Turkish version of Preservice Teachers' ICT Competencies Scale was determined to have good psychometric properties to be used in Turkish context.
\end{abstract}

\section{Öğretmen Adayları için Bilgi ve İletişim Teknolojileri Yeterlikleri Ölçeğinin Türk Kültürüne Uyarlanması}

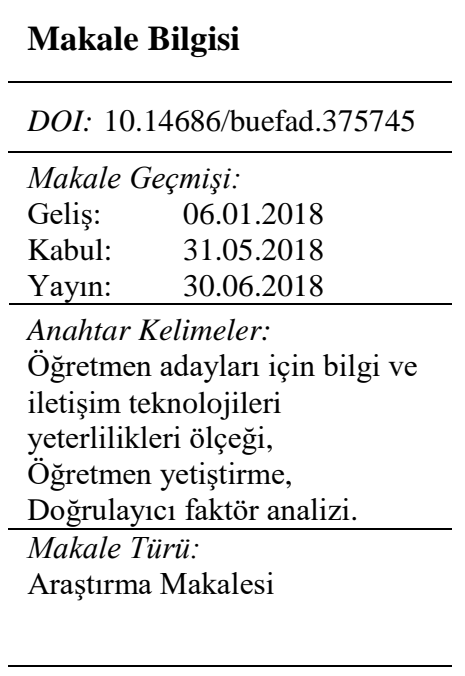

\section{$\ddot{O} z$}

Bu çalışmada Tondeur, Aesaert, Pynoo, Braak, Fraeyman ve Erstad (2017) tarafından geliştirilmiş olan Öğretmen Adayları için BİT Yeterlikleri Ölçeğinin Türk dili ve kültürüne uyarlanması amaçlanmıştır. Araştırma 2017-2018 Öğretim yılı Güz döneminde Gaziosmanpaşa Üniversitesi'nde öğrenim görmekte olan 206 öğretmen adayı üzerinde yürütülmüştür. Doğrulayıcı faktör analizi sonucunda, ölçeğin iki faktörlü özgün formunun doğrulandığ 1 görülmüştür. Yakınsak, ayırt edici ve eş zamanlı geçerliği sınamak için uyarlanan formdan elde edilen veriler ile Genel BİT Eğilimi, Gerçeklik Şoku Beklentisi ve Öğretmen Adaylarının Eğitimde Bilgi ve İletişim Teknolojilerini Kullanmaya İlişkin Yeterlilik Algıları ölçeklerinden elde edilen puanlar arasındaki korelasyon incelenmiş ve uyarlanan ölçeğin ilgili geçerlik türlerine sahip olduğu belirlenmiştir. Güvenirlik analizi için hesaplanan Cronbach alfa iç tutarlılık katsayısı, ölçek boyutlarından elde edilen verilerin güvenilir olduğunu ortaya koymuştur. Araştırmanın sonucu olarak, Öğretmen Adayları için Bilgi ve İletişim Teknolojileri Yeterlikleri Ölçeğinin Türkçe formuna ait psikometrik özelliklerin iyi düzeyde olduğu belirlenmiştir.

\footnotetext{
*Corresponding Author: mfatihalkan@hotmail.com

${ }^{a}$ Res. Asst., Tokat Gaziosmanpasa University, Tokat/Turkey, https://orcid.org/0000-0002-5600-0160

b Asst. Prof. Dr., Tokat Gaziosmanpasa University, Tokat/Turkey, https://orcid.org/0000-0002-6188-7173
} 


\section{Introduction}

The use of information and communication technologies (ICT) in education aims at improving the student performance and is assumed to increase the effectiveness and efficiency of teaching and learning process (Tasir, Abour, Halim, \& Harun, 2012). At this point, teachers have a vital role since the widespread use of ICT requires teachers to acquire novel skills and competencies so that the students could learn effectively (Hew \& Leong, 2011).

The requirement for teachers' integration of ICT into educational practice has been accepted by increasing number of experts because some benefits of ICT have been revealed. Some of these benefits are getting easier access to digital information, enabling student-centered and self-regulated learning, forming a creative learning environment, encouraging cooperative learning, providing more opportunities for the development of higher order thinking skills, and increasing the quality of teaching and learning (Fu, 2013). Within this scope, a variety of countries such as USA, Malaysia, and Portugal has initiated large-budget projects to ensure ICT integration into education (Brenner \& Brill, 2016; Chan, 2002; Godinho, 2015). A similar project has been carried out in Turkey. The project aimed at dissemination of interactive whiteboard, internet access, tablets, and material portals to each school in the country (Ministry of National Education [MEB], 2017). However, making use of these affordances provided by the ministry depends on the teachers' knowledge or competency of technology (Mumtaz, 2000).

Technology competencies can be defined as a series of knowledge and skills that teachers have and enable them to reach a variety of technological resources (Suarez-Rodríguez, Almerich, Díaz-García, \& Fernandez-Piqueras, 2012). Within this scope, a number of theoretical models regarding the ICT competencies of teachers has been described. One of these models was presented in a study conducted by Ferrari (2013) within the body of European Commission. Accordingly, digital competencies were composed of five dimensions which were information, communication, content creation, safety, and problem solving. In a model developed by UNESCO (2008), a schedule that can be implemented by countries which aims at improving teachers' ICT competencies was provided. Technology literacy, knowledge deepening, and knowledge creation were defined as the dimensions of the model (UNESCO, 2008). On the other hand, International Society for Technology in Education (ISTE) classified teacher competencies under five categories (ISTE, 2014). These categories are listed as facilitating and inspiring student learning and creativity, designing and developing digital age learning experiences and assessments, modelling digital age work and learning, promoting and modelling digital citizenship and responsibility, and engaging in professional growth and leadership (ISTE, 2014). Additionally, a variety of institutions and researchers have proposed similar competency frameworks as well (Baylor \& Ritchie, 2002; European Institute for E-Learning, 2017; Hsu, 2010; Markauskaite, 2007; Virginia Technology Standards for Instructional Personnel, 1998).

Considering the important role of ICT in every aspect of life, its promising outputs for increasing the quality of education, and large-budget projects that aim to ensure its integration into education, it is expected from teacher education institutions to equip their students with ICT competencies. However, deciding whether this expectation is fulfilled or not requires determination of preservice teachers' ICT competencies (Tondeur et al., 2017). When the national literature was reviewed, it was observed that there were some instruments to measure the teachers' or preservice teachers' ICT competencies. For example, in their study aiming at determining the preservice teachers' perceived competencies regarding the use of ICT in education, Şad and Nalçacı (2015) developed a scale composed of 30 items and a single factor. It was based on Teaching Profession General Competencies (MEB, 2006). When this data collection tool was examined in detail, it was observed that the items focused mostly on the use of some devices and software used in classroom and the ICT knowledge level. A similar data collection tool was developed by Şimşek and Yazar (2016) based on International Society for Technology in Education Standards (ISTE, 2014). It was composed of 40 items and five factors named as (1) Facilitating and inspiring student learning and creativity; (2) Designing and developing digital age learning experiences and assessments; (3) Modelling digital age work and learning; (4) Promoting and modelling digital citizenship and responsibility; and (5) Engaging in professional growth and leadership.

Both of the tools described in the previous paragraph have some disadvantages. First of all, both tools are based on only one theoretical foundation. Şad and Nalçacı (2015) focused on Teaching Profession 
General Competencies (MEB, 2006) while Şimşek and Yazar (2016) focused on ISTE Standards (ISTE, 2014) while developing the tools. On the other hand, Preservice Teachers' Information and Communication Technology Competencies Scale (Tondeur et al., 2017) which was aimed to be adapted into Turkish in the current study was based on more than 20 competency frameworks including Virginia Technology Standards for Instructional Personnel (1998), ICT Competency Standards for Teachers (UNESCO, 2008), and The ELearning Competency Framework for Teachers and Trainers (European Institute for E-Learning, 2017). The instrument adapted in this study has a broader theoretical background and it is more comprehensive. In addition, the adapted tool is shorter, which is another advantage since short scales are preferred as they are easier to be used (Morin, Scalas, Vispoel, Marsh, \& Wen, 2016). Within this context, the adapted tool is composed of 19 items while the tools developed by Şad and Nalçacı (2015) and Şimşek and Yazar (2016) are composed of 30 and 40 items, respectively. With reference to these advantages, this study aimed at adapting Preservice Teachers' Information and Communication Technology Competencies Scale, developed by Tondeur, Aesaert, Pynoo, Braak, Fraeyman and Erstad (2017), into Turkish language and culture.

\section{Method}

This section presents information about participants of the study, data collection tools, data collection process, procedure and data analysis.

\section{Participants}

The participants of this study were composed of a total of 206 (163 Female, 43 Male) preservice teachers studying at the School of Education in Gaziosmanpaşa University during 2017-2018 academic year. Their age ranged from 18 to 25 , and the mean of their age was $20.50(\mathrm{SD}=1.13)$. The participants were studying at a variety of departments which were Social Studies Education $(n=43,21 \%)$, Science Education $(n=68$, $33 \%)$, and Primary Education $(n=95,46 \%)$. Of all the participants, 69 (34\%) were second-year students while $137(66 \%)$ were third-year students.

Following the development steps of the original scale as proposed by Tondeur and his colleagues (2017), the participants were chosen among the students who were the preservice teachers studying at the Faculty of Education. Additionally, the participants who were willing to participate to the study were selected from the Faculty of Education where the researchers work so that the data collection process could be more efficient. Within this context, convenience sampling technique was used.

Some criteria were considered while determining the appropriate number of participants for the confirmatory factor analysis. In their simulation study, Wolf, Harrington, Clark, and Miller (2013) demonstrated that at least 150 participants were required to conduct confirmatory factor analysis with models involving two factors with more than eight indicators. Similarly, Kline (2016) stated that the common practice for minimum acceptable number of participants was 200 for using confirmatory factor analysis. In this study, the confirmatory factor analysis was conducted using the data obtained from 206 participants.

\section{Data Collection Tools}

The data of this study were obtained using Preservice Teachers' Information and Communication Technology Competencies Scale. In addition to this data collection tool, General ICT Tendency subscale of ICT Attitude Scale was used to test the convergent validity. Convergent validity is indicated by finding strong relationships among theoretically similar constructs (Brown, 2006). Thus, General ICT Tendency subscale was used in this study to examine the convergent validity since it has a similar theoretical structure with ICT competencies scale. The divergent validity was tested using the data obtained from Reality Shock Expectation Scale. This type of validity is indicated by not finding a high correlation between theoretically distinct constructs (Brown, 2006). Therefore, Reality Expectation Scale was used since it is a different construct from ICT competencies. Finally, the concurrent validity was tested using the data obtained from Prospective Teachers' Perceived Competencies about Integrating ICT into Education Scale. Concurrent validity is seen when scores obtained from a new measure are related to the scores obtained from an established measure of the same variable (Gravetter \& Forzano, 2012). Thus, evidence for concurrent validity was sought by administering the adapted scale and Prospective Teachers' Perceived Competencies about Integrating ICT into Education Scale simultaneously. 
Preservice teachers' information and communication technology competencies scale. This data collection tool was a self-report measure developed by Tondeur, Aesaert, Pynoo, Braak, Fraeyman, and Erstad (2017) in English language. In the original study involving the development steps of the scale, the first step was to write items following a comprehensive literature review. Then, the stakeholders (i.e., preservice teachers, teacher trainers, ICT coordinators and researchers) evaluated the first version of the items. After this process, a questionnaire consisting of 19 items was obtained. The items are rated on a 5point Likert scale ranging from 1 (strongly disagree) to 5 (strongly agree). This form was sent to 20 teacher training institutions in Belgium. At the end of the process, 931 preservice teachers took part in the study. The data was divided into two subsamples randomly. Exploratory factor analysis was conducted on subsample 1, and confirmatory factor analysis was conducted on the subsample 2. The exploratory factor analysis revealed a two factorial structure and the model explained $56.3 \%$ of the total variance. The factor loadings ranged from 0.57 to 0.85 . The first factor involving 11 items was named as ICT competencies to support pupils for ICT use. This factor aimed at measuring the extent to which preservice teachers are competent to educate pupils in the use of ICT for learning processes. One of the items from this factor is "I'm able to support pupils to work together with ICT." The second factor involving 8 items was named as ICT competencies for instructional design. This factor aimed at measuring the degree to which preservice teachers are competent to use ICT to support and strengthen their instructional practice. An example item from this factor is "I'm able to track the learning progress of pupils in a digital way." The two-factor solution was tested through confirmatory factor analysis using the subsample 2 . Considering the fit indexes (GFI = 0.91; $\mathrm{AGFI}=0.88 ; \mathrm{TLI}=0.95 ; \mathrm{CFI}=0.96 ; \mathrm{RMSEA}=0.06$ ) and the factor loadings (varying from 0.65 to 0.84 ), the authors concluded that the two-factor solution was confirmed. Moreover, the residuals of items 3 and 4 and items 15 and 16 were allowed to correlate since they measured similar characteristics. Finally, the internal consistency was checked calculating the Cronbach alpha coefficient. The internal consistency coefficients of the first $(\alpha=0.94)$ and second factor $(\alpha=0.89)$ showed that the items had high internal consistency. The higher scores obtained from the factors indicate that the participants perceive themselves more competent of that factor while the lower scores indicate that the participants perceive themselves less competent (Tondeur et al., 2017).

ICT attitude scale. This data collection tool was developed by Günbatar (2014). The items are rated on a 5-point Likert scale ranging from 1 (strongly disagree) to 5 (strongly agree). The developers of the scale conducted exploratory and confirmatory factor analysis on the data obtained from a total of 381 undergraduates. As a result of exploratory factor analysis, a scale composed of 10 factors and 54 items was obtained. The items that were loaded on more than one factor and inappropriate to the overall structure of the scale were excluded from the scale. Finally, the scale was composed of 23 items loaded under 5 factors. The factor loadings ranged from 0.60 to 0.89 . The confirmatory factor analysis confirmed the model obtained from exploratory factor analysis $(\mathrm{RMSEA}=0.058$; $\mathrm{NFI}=0.96$; $\mathrm{NNFI}=0.97$; $\mathrm{CFI}=0.98$; IFI $=$ 0.98; GFI = 0.90; AGFI =0.87). The reliability of the scale was checked using Cronbach alpha and testretest reliability coefficients. The internal consistency coefficients of the factors ranged from 0.76 and 0.92 . The test-retest reliability coefficients of the factors ranged from 0.71 and 0.93 (Günbatar, 2014). In the current study, the subscale named as General ICT Tendency, which was composed of 6 items, was used. The items of General ICT Tendency subscale aims at measuring the individuals' attitudes towards ICT use. One of the items in this subscale is "I like to use ICT in daily life." In the original study, internal consistency coefficient and test-retest reliability coefficient were estimated to be 0.89 and 0.90 , respectively (Günbatar, 2014). In the current study, internal consistency coefficient of General ICT Tendency scale was found to be .87 .

Reality shock expectation scale. This tool was originally developed by Kim and Cho (2014) and adapted into Turkish by Özdemir and Büyükgöze (2016). It was composed of 9 items and a single factor. The items are rated on a 7-point Likert scale ranging from 1 (not at all true) to 7 (very true). Higher scores obtained from the scale indicate higher expectation of reality shock. This scale aims at measuring the preservice teachers' expectations of reality shock in their first year of teaching. One sample item is "Classroom management will be different from what we were taught theoretically." The adaptation study involved 120 preservice teachers. The confirmatory factor analysis confirmed the original single-factor structure (AGFI $=0.86 ; \mathrm{GFI}=0.92 ; \mathrm{NFI}=0.89 ; \mathrm{CFI}=0.94 ; \mathrm{IFI}=0.84 ; \mathrm{SRMR}=0.16 ; \mathrm{RMSEA}=0.08)$ (Özdemir \& Büyükgöze, 2016). The Cronbach alpha coefficient of the scale was found to be $0.88,0.78$, and 0.82 in the original (Kim \& Cho, 2014), adaptation (Özdemir \& Büyükgöze, 2016), and current study, respectively. 
Prospective teachers' perceived competencies about integrating ICT into education scale. This tool was developed by Şad and Nalçacı (2015) based on the 6 main competency fields, 31 sub-competency fields, and 233 performance indicators proposed by Ministry of National Education. It aims at measuring teachers' perceptions of their ICT competencies. One sample item is "to be able to present lesson materials using interactive whiteboard, projector, overhead projector etc." It was composed of 30 items loaded under single factor. The items are rated on a 5-point Likert scale ranging from 1 (highly incompetent) to 5 (highly competent). The data were obtained from 409 preservice teachers and exploratory factor analysis was conducted. The results showed that $48 \%$ of the total variance was explained. The factor loadings ranged from 0.52 to 0.76 . The Cronbach alpha coefficient and Guttman split-half coefficient were found to be 0.96 and 0.93, respectively (Şad \& Nalçacı, 2015). In the current study, Cronbach alpha coefficient was found to be .95 .

\section{Data Collection Process}

The data of this study were collected from a total of 206 preservice teachers studying at the School of Education in Gaziosmanpaşa University during 2017-2018 academic year. The data were collected in the classroom environment by the researchers. The aim of the study and expectations from the participants were explained to the students. The survey was administered to the volunteer students. It took about 15 minutes to complete the data collection instruments.

\section{Procedure and Data Analysis}

The adaptation process of Preservice Teachers' Information and Communication Technology Competencies Scale into Turkish was carried out based on the steps proposed by Borsa, Damásio, and Bandeira (2012) for scale adaptation process. Accordingly, the procedures that were followed in the study were (1) translation process, (2) synthesis of the translated versions, (3) evaluation by committee of experts, and (4) evaluation by intended sample (Borsa, Damásio, \& Bandeira, 2012). The back-translation process was not carried out in this study since the meaning was emphasized and due to the worry about the loss of meaning and context that could be brought by back-translation (Gudmundsson, 2009).

Within the context of steps proposed by Borsa, Damásio, and Bandeira (2012), the corresponding author Dr. Jo Tondeur was contacted through e-mail, and his permission to adapt the scale was granted. Then, (1) the items were translated into Turkish by three interpreters who were graduated from English Language Teaching programs and were fluent in both languages. (2) The translated items were reviewed by the authors who were fluent in English. The items representing the measured quality best, and the items with the most consistent translations were chosen. (3) Expert opinion form was developed using the synthesized Turkish items. This form was sent to four experts, two of whom were Turkish language experts, and two of whom were experts in the field of Computers and Instructional Technologies. Minor revisions involving punctuation, word choice, and grammar were made in four items based on the feedbacks. (4) Then, a focus group interview was conducted with six preservice teachers. Their opinions were taken, and minor revisions in two items were made to improve meaning and comprehensibility. Improved as a result of expert opinions and focus group interview, the Turkish and the original English form was examined by both authors, and it was observed that both forms were linguistically equivalent.

Confirmatory factor analysis is associated with theory testing that it is used when the factor structure of an already developed scale is hypothesized and tested with a new sample (Kline, 2016; Tabachnick \& Fidell, 2013). Accordingly, confirmatory factor analysis was conducted in this study to test whether the adapted scale demonstrates the same factorial structure of the original version. Moreover, convergent, divergent, and concurrent validity analyses were conducted. The reliability was checked through estimating the Cronbach alpha coefficients. These analyses were conducted using SPSS 20, AMOS 24 and Mplus 6.12 software. The alpha value was set as.05 in this study.

\section{Findings}

\section{Descriptive Statistics}


Means, standard deviations, minimum and maximum values, skewness and kurtosis values of the items, subscales, and total score of the Preservice Teachers' Information and Communication Technology Competencies Scale are presented in Table 1. Obtaining a mean score lower than 2.5, which is the neutral lower limit, indicates that the participants perceived themselves incompetent in terms of that dimension while obtaining a mean score higher than 3.5, which is the neutral upper limit, shows that the participants perceived themselves competent. When the mean scores of responses given to items were examined, it was observed that the majority of items (except for item 13: "I am able to (re)design ICT applications in view of a specific educational setting") had mean scores higher than 3.5. Similarly, the mean scores of the subscales and total score were higher than 3.5, showing that the participants perceived themselves competent about supporting pupils for ICT use, instructional design, and ICT use in general.

Table 1. Means, Standard Deviations, Minimum and Maximum Values, Skewness and Kurtosis Values

\begin{tabular}{|c|c|c|c|c|c|c|}
\hline Subscales and Items & Mean & SD & Min. & Max. & Skewness & Kurtosis \\
\hline ICTC-PU & 4.08 & .60 & 1.45 & 5.00 & -1.60 & 4.79 \\
\hline ICTC-ID & 3.87 & .59 & 1.50 & 5.00 & -.93 & 1.91 \\
\hline ICT-Total & 3.99 & .55 & 1.58 & 5.00 & -1.38 & 4.30 \\
\hline Item 1 & 4.15 & .81 & 1 & 5 & -1.45 & 3.41 \\
\hline Item 2 & 3.86 & .88 & 1 & 5 & -.94 & 1.11 \\
\hline Item 3 & 4.14 & .72 & 1 & 5 & -.98 & 2.07 \\
\hline Item 4 & 4.09 & .82 & 1 & 5 & -1.33 & 2.94 \\
\hline Item 5 & 4.02 & .81 & 1 & 5 & -1.02 & 1.86 \\
\hline Item 6 & 4.21 & .81 & 1 & 5 & -1.35 & 2.87 \\
\hline Item 7 & 4.02 & .83 & 1 & 5 & -1.21 & 2.66 \\
\hline Item 8 & 4.17 & .77 & 1 & 5 & -1.38 & 3.54 \\
\hline Item 9 & 4.06 & .88 & 1 & 5 & -1.10 & 1.63 \\
\hline Item 10 & 4.11 & .85 & 1 & 5 & -1.12 & 1.77 \\
\hline Item 11 & 4.00 & .91 & 1 & 5 & -1.01 & 1.15 \\
\hline Item 12 & 4.00 & .74 & 2 & 5 & -.69 & .68 \\
\hline Item 13 & 3.46 & .96 & 1 & 5 & -.22 & -.27 \\
\hline Item 14 & 4.10 & .79 & 1 & 5 & -1.31 & 3.36 \\
\hline Item 15 & 3.87 & 1.03 & 1 & 5 & -.89 & .46 \\
\hline Item 16 & 3.99 & .90 & 1 & 5 & -.83 & .67 \\
\hline Item 17 & 4.08 & .84 & 1 & 5 & -1.12 & 1.81 \\
\hline Item 18 & 3.69 & .95 & 1 & 5 & -.57 & .14 \\
\hline Item 19 & 3.82 & .81 & 1 & 5 & -.47 & .47 \\
\hline
\end{tabular}

Note: ICTC-PU: ICT competencies to support pupils for ICT use, ICTC-ID: ICT competencies for instructional design

\section{Findings Regarding the Confirmatory Factor Analysis}

Confirmatory factor analysis (CFA) was conducted in order to test the factor structure of the Turkish version of the Preservice Teachers' Information and Communication Technology Competencies Scale 
(Tondeur et al., 2017). Prior to this analysis, the assumptions of CFA, which were outliers, univariate and multivariate normality, and multicollinearity, were checked (Flora, LaBrish, \& Chalmers, 2012).

Outliers. The multivariate outliers were checked using Mahalanobis distance values. Ten outliers were determined to have smaller values than the critical value of $\mathrm{p}<.001$ (Tabachnick \& Fidell, 2013). CFA was conducted on the data twice by both including and excluding outliers. It was observed that the outliers weren't influential since they didn't change the results. Therefore, the outliers were maintained in the dataset.

Univariate and multivariate normality. Univariate normality was checked using skewness and kurtosis values, and Q-Q plots. The skewness and kurtosis values were smaller than 3, which indicated univariate normality (Kline, 2016). Moreover, Q-Q plots revealed a 45-degree line, indicating that departures from normality were acceptable (Tabachnick \& Fidell, 2013). Multivariate normality was checked using Mardia's test through AMOS software. A multivariate kurtosis value smaller than 10 (Shen, Schüttemeyer, \& Braun, 2009) and a critical ratio smaller than 1.96 indicate multivariate normality (Mardia, 1970). The analysis revealed that multivariate kurtosis value was 147.72 and critical ratio was 37.52 , which indicated that the data violated the assumption of multivariate normality.

Multicollinearity. The multicollinearity was checked by estimating the correlations among the items and factors. The correlation coefficients among the items ranged from .13 to .66. The estimated correlation coefficient between the two factors was found to be .80 . These values were smaller than the critical value of .90 (Kline, 2016). Therefore, there was no multicollinearity problem in the data.

Model fit. Upon the examination of CFA assumptions, it was observed that the data did not meet the multivariate normality assumption. As a result, maximum likelihood estimation with robust standard errors (MLR) method, an estimation method used in SEM analyses which did not require multivariate normality, was used in this study (Muthen \& Muthen, 2007). The model fit was evaluated using Chi-square/degree of freedom, CFI, RMSEA, SRMR, which were recommended by MacCallum, Browne, and Sugawara (1996), and TLI, which was recommended by Brown (2006).

Accordingly, $\chi^{2}(149)=235.962, p<.05$ was found. Although the significant $p$ value indicates the rejection of the model (Dilalla, 2000), it is recommended to evaluate it with other indexes since chi-square is sensitive to correlations and sample size (Kline, 2016). The other indexes were $\chi^{2} / \mathrm{df}=1.58, \mathrm{CFI}=.93$, RMSEA=.05 (90\% confidence interval=.040-.066), and SRMR= .05. The findings show a good fit of the data to the model (Kline, 2016). As seen in Table 2, the obtained values are within the acceptable thresholds, and they are close to the findings obtained in the original study (Tondeur et al., 2017).

Table 2. Findings of the Fit Indexes

\begin{tabular}{lccl}
\hline Index & Original Scale & Turkish Version & Acceptable Thresholds \\
\hline $\mathrm{X}^{2} / \mathrm{df}$ & - & 1.58 & $\leq 5$ (Bollen, 1989) \\
CFI & .96 & .93 & $\geq .90$ (Marsh, Hau, \& Wen, 2004) \\
TLI & .95 & .92 & $\geq .90$ (Baumgartner \& Homburg, 1996) \\
RMSEA & .06 & .05 & $\leq .08$ (MacCallum, Browne, \& Sugawara, 1996) \\
SRMR & - & .05 & $\leq .08$ (Kline, 2016) \\
\hline
\end{tabular}

The factor loadings of the items under ICT competencies to support pupils for ICT use ranged from .53 to .78; the items under ICT competencies for instructional design ranged from .44 to .74. Thus, factor loadings were observed to have values bigger than .30 and loaded under the expected factors (Hair, Black, Babin, Anderson, \& Tatham, 2006). The factor loadings and standard error values are presented in Figure 1 . 


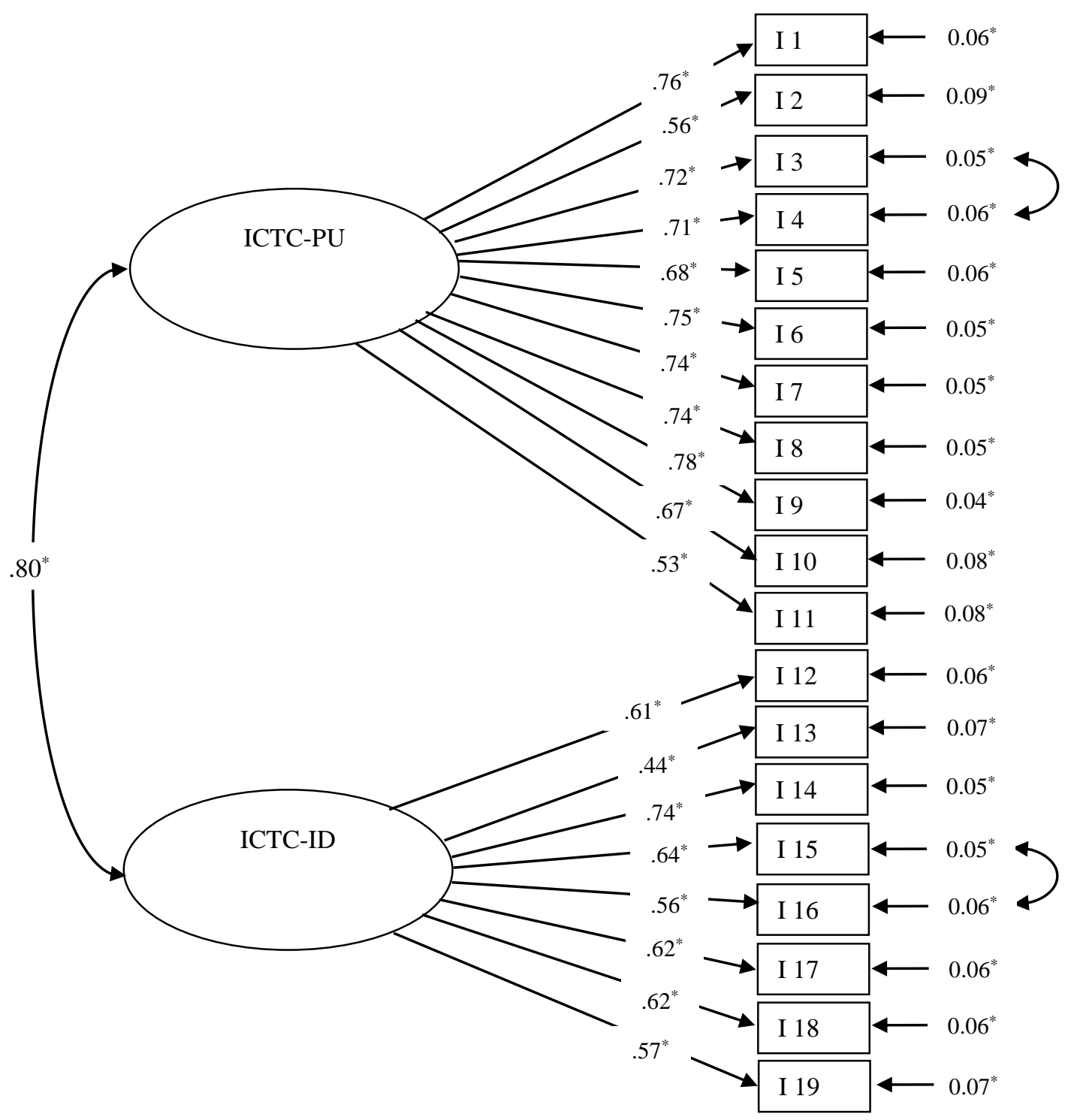

Figure 1. Factor Loadings and Standard Errors

Note: ${ }^{*} p<.05$, I1-I19: Scale items, ICTC-PU: ICT competencies to support pupils for ICT use, ICTCID: ICT competencies for instructional design

\section{Findings Regarding the Convergent, Divergent, and Concurrent Validity Analyses}

Pearson correlation coefficients between the scores obtained from the subscales of Preservice Teachers' Information and Communication Technology Competencies Scale and other scales were used to test the convergent, divergent, and concurrent validity. Accordingly, the scores obtained from ICT competencies to support pupils for ICT use significantly and positively correlated with the scores obtained from general ICT tendency $(r(206)=0.51, p<.05)$ and with the scores obtained from prospective teachers' perceived competencies about integrating ICT into education scale $(r(206)=0.48, p<.05)$. It did not significantly correlate with the scores obtained from reality shock expectation scale $(r(206)=0.11, p>.05)$. Similarly, the scores obtained from ICT competencies for instructional design significantly and positively correlated with the scores obtained from general ICT tendency $(r(206)=0.56, p<.05)$ and with the scores obtained from prospective teachers' perceived competencies about integrating ICT into education scale $(r(206)=$ $0.62, p<.05)$. It didn't significantly correlate with the scores obtained from reality shock expectation scale 
$(r(206)=0.06, p>.05)$. In conclusion, the statistically significant and positive correlations between the scores obtained from the subscales of Preservice Teachers' Information and Communication Technology Competencies Scale and general ICT tendency indicated that the results confirmed convergent validity. The absence of statistically significant correlations between the scores obtained from the subscales of Preservice Teachers' Information and Communication Technology Competencies Scale and reality shock expectation scale indicated that the results confirmed divergent validity. Finally, the statistically significant and positive correlations between the scores obtained from the subscales of Preservice Teachers' Information and Communication Technology Competencies Scale and prospective teachers' perceived competencies about integrating ICT into education scale indicated that the results confirmed concurrent validity (Table 3 ).

Table 3. Correlation Coefficients among the Scores obtained from Different Scales

\begin{tabular}{lccccc}
\hline Scales & $\mathbf{1}$ & $\mathbf{2}$ & $\mathbf{3}$ & $\mathbf{4}$ & $\mathbf{5}$ \\
\hline 1. ICT competencies to support pupils for ICT use & 1.00 & & & & \\
2. ICT competencies for instructional design & $.68^{*}$ & 1.00 & & & \\
3. General ICT tendency & $.51^{*}$ & $.56^{*}$ & 1.00 & & \\
4. Prospective teachers' perceived competencies & $.48^{*}$ & $.62^{*}$ & $.48^{*}$ & 1.00 \\
about ICT & .11 & .06 & .12 & .09 & 1.00 \\
5. Reality shock expectation & & & & &
\end{tabular}

\section{Findings Regarding the Reliability Analysis}

The reliability of the scores obtained from the adapted scale was examined using the internal consistency coefficients of the subscales. Cronbach alpha coefficients of ICT competencies to support pupils for ICT use and ICT competencies for instructional design were found to be .91 and .82 , respectively. As the internal consistency coefficient that is equal to or bigger than .70 is accepted as reliable (Kline, 2016; Nunnaly, 1978), it was found that the data obtained from Preservice Teachers' Information and Communication Technology Competencies Scale had a high level of reliability.

\section{Discussion and Conclusion}

There has been much emphasis on the use of standardized and validated data collection tools (Gjersing, Caplehorn, \& Clausen, 2010). One of the reasons behind this emphasis is that these kinds of tools enable making comparisons of the results of national and international studies (Van Widenfelt, Treffers, de Beurs, Siebelink, \& Koudijs, 2005; Laake, Olsen, \& Benestad, 2007). Moreover, the use of adapted scales increases the certainty with which the tools accurately reflect what they are expected to measure (Laake, Olsen, \& Benestad, 2007). With the goal of providing researchers with a standardized and validated data collection instruments to be used for international comparisons, this study aimed at adapting the Preservice Teachers' Information and Communication Technology Competencies Scale, which was developed by Tondeur and his colleagues (2017), into Turkish language and culture. Within this scope, validity and reliability analyses were conducted on the data obtained from Turkish speaking preservice teachers.

First of all, Preservice Teachers' Information and Communication Technology Competencies Scale, which was developed by Tondeur and his colleagues (2017), was composed of 19 items and two factors. During the item generation process, more than 20 ICT competency frameworks for teachers or preservice teachers were reviewed, and the items were based on these theoretical foundations. The instruments developed by Şad and Nalçacı (2015) and Şimşek and Yazar (2016) aim to measure ICT competencies as well. These instruments were composed of 30 and 40 items, respectively. Each of them were developed based on one theoretical framework. Within this context, it can be stated that the instrument adapted in the current study has a more comprehensive theoretical foundation. Moreover, the instrument adapted in this study is much shorter, which poses another advantage.

The linguistic equivalence of the Turkish and English form was ensured through experts' opinions. The construct validity was tested using confirmatory factor analysis. The CFA results showed that the Turkish 
version had the same two factorial structure as the original version. The examination of fit indexes revealed that the values obtained from the original and Turkish form were similar. Convergent validity was tested by estimating the correlation coefficient between the scores obtained from Turkish version of the Preservice Teachers' ICT Competencies Scale and general ICT tendency scale, which was developed by Günbatar (2015). A statistically significant correlation was expected prior to the analysis since both constructs had common aspects theoretically. As expected, a statistically significant and positive correlation was found. The divergent validity was tested by estimating the correlation coefficients between the scores obtained from Turkish version of the Preservice Teachers' ICT Competencies Scale and reality shock expectation scale, which was developed by Kim and Cho (2014) and adapted into Turkish by Özdemir and Büyükgöze (2016). No statistically significant correlation was expected since these two constructs were theoretically different. As expected, no statistically significant correlation between these two constructs were observed. The concurrent validity was tested by estimating the correlation coefficient between the scores obtained from the Turkish version of the Preservice Teachers' ICT Competencies Scale and prospective teachers' perceived competencies about integrating ICT into education scale, which was developed by Şad and Nalçacı (2015). A statistically significant and positive correlation was expected prior to the analysis since these two scales were measuring the same construct. The results revealed a statistically significant and positive correlation, as expected. These findings supported that the Turkish version of the Preservice Teachers' ICT Competencies Scale had the construct, convergent, divergent, and concurrent validity. The internal consistency of the Turkish version of the Preservice Teachers' ICT Competencies Scale was examined by calculating Cronbach alpha coefficients. Accordingly, internal consistency coefficients of the data obtained from ICT competencies to support pupils for ICT use and ICT competencies for instructional design were found to be .91 and .82, respectively. These findings are supported by the findings of Tondeur and his colleagues (2017). These findings indicated that the data obtained from the Turkish version of the Preservice Teachers' ICT Competencies Scale had high level of internal consistency reliability. As a result of the study, the findings of validity and reliability analyses showed that Turkish version of the Preservice Teachers' ICT Competencies Scale is a suitable tool to measure preservice teachers' competency levels of ICT. In conclusion, Turkish version of the Preservice Teachers' ICT Competencies Scale is a data collection instrument that has the adequate psychometric qualities for measuring Turkish speaking preservice teachers' ICT competencies.

The future studies are recommended to repeat the validity and reliability analyses on different samples and present evidence on these aspects. Moreover, measurement invariance of Preservice Teachers' ICT Competencies Scale across gender, department and grade level should be investigated.

Considering the direction where today's education environments are leading, the importance of teachers' ICT skills becomes clear. It is expected that development of these skills during the undergraduate education will prevent preservice teachers from experiencing ICT-related issues once they become teachers. From this viewpoint, to what extent preservice teachers possess ICT competencies is required to be revealed in order provide them with appropriate education that they need. In other words, it is highly important to determine preservice teachers' ICT competencies to plan, develop, and evaluate preservice education programs. Thus, teaching process can be designed based on preservice teachers' needs, and the effectiveness of that process can be evaluated.

\section{Acknowledgments}

The summary of this study was presented in International Educational Technology Symposium which was organized between 27 and 28 October 2017 in Sivas, Turkey. The Turkish version of preservice teachers' information and communication technology competencies scale can be seen in Appendix 1. It is allowed for researchers to use it for research purposes by citing properly. 


\title{
Öğretmen Adayları için Bilgi ve İletişim Teknolojileri Yeterlikleri Ölçeğinin Türk Kültürüne Uyarlanması
}

\author{
Giriş
}

Eğitimde bilgi ve iletişim teknolojilerinin (BİT) kullanımı ile öğrenci performansını artırmak amaçlanmakta ve bunun öğretme ve öğrenme sürecinin etkililiğini ve verimliliğini artırması umulmaktadır (Tasir, Abour, Halim, \& Harun, 2012). Bu noktada öğretmenlerin rolü oldukça önemlidir çünkü eğitimde BİT'in giderek daha fazla kullanılarak öğrencilerin daha etkili öğrenmeler gerçekleştirebilmesi için öncelikle öğretmenlerin yeni beceri ve yeterlikler edinmeleri gerekmektedir (Hew \& Leong, 2011).

Öğretmenlerin bilgi ve iletişim teknolojilerini eğitim uygulamalarına yansıtmaları gerekliliği giderek daha fazla kabul görmeye başlamıştır. Bunun nedeni, BíT'in eğitim ortamlarına yönelik sağladığı pek çok faydanın bulunmasıdır. Örneğin, BİT'in öğrencilerin dijital bilgilere etkili bir şekilde erişmelerini kolaylaştırdığı, öğrenci merkezli ve öz-yönelimli öğrenmeyi desteklediği, yaratıcı bir öğrenme ortamı oluşturduğu, işbirlikli öğrenmeyi teşvik ettiği, üst düzey düşünme becerilerinin gelişimi için daha fazla olanak sunduğu, öğretim ve dolayısıyla öğrenme niteliğini artırdığı görülmüsstür ( $\mathrm{Fu}, 2013)$. Bu bağlamda $\mathrm{ABD}$, Malezya ve Portekiz gibi birçok ülkede BİT'in eğitime entegrasyonunu amaçlayan geniş çaplı projeler yürütülmektedir (Brenner \& Brill, 2016; Chan, 2002; Godinho, 2015). Benzer bir proje de FATİH projesi adı altında Türkiye'de uygulanmaktadır. FATİH projesi ile etkileşimli akıllı tahtalar, internet erişimi, tabletler ve materyal portalları gibi teknolojilerin ülkenin bütün okullarına yayılması amaçlanmıştır (Milli Eğitim Bakanlığı [MEB], 2017). Ancak sunulan bu gibi bilgi ve iletişim teknolojileri imkânlarından yararlanılması, öğretmenlerin teknoloji bilgisi veya yeterliğine bağlıdır (Mumtaz, 2000).

Teknoloji yeterlikleri, öğretmenlerin sahip olduğu ve öğretim sürecinde kendilerine çeşitli teknolojik kaynaklara ulaşma imkânı veren bir dizi bilgi ve beceri olarak tanımlanabilir (Suarez-Rodríguez, Almerich, Díaz-García, \& Fernandez-Piqueras, 2012). Bu noktada öğretmenlerin sahip olması gereken BİT yeterliklerine ilişkin çeşitli kuramsal modeller tanımlanmıştır. Bu amaçla hazırlanan modellerden biri Ferrari (2013) tarafindan Avrupa Komisyonu bünyesinde gerçekleştirilen çalı̧̧mada sunulmuştur. Bu rapora göre dijital yeterlikler bilgi, iletişim, içerik oluşturma, güvenlik ve problem çözme olmak üzere beş boyuttan oluşmaktadır. UNESCO (2008) tarafindan geliştirilen çerçevede ise öğretmenlerin BİT yeterliklerini geliştirmek ülkelerin uygulayabileceği bir izlence sunulmaktadır. Bu doğrultuda teknoloji okuryazarlığı, bilginin derinleştirilmesi ve bilgi oluşturma boyutları tanımlanmıştır (UNESCO, 2008). Diğer taraftan Uluslararası Eğitim Teknolojisi Standartları (ISTE), öğretmen yeterliklerini beş boyutta tanımlamıştır (ISTE, 2014). Bu yeterlikler; öğrenci öğrenme ve yaratıcılığını teşvik etme ve tetikleme, dijital çağ öğrenme deneyimleri ve değerlendirme yöntemleri tasarlama ve geliştirme, dijital çağ işlerinde ve öğrenmede model olma, dijital vatandaşlık ve sorumluluğu teşvik etme ve model olma, mesleki gelişim ve liderlik gösterme olarak sıralanmaktadır (ISTE, 2014). Bunlara ek olarak alanyazında çeşitli kurum ve yazarların benzer yeterlik çerçeveleri ortaya koyduğu da görülmektedir (Baylor \& Ritchie, 2002; European Institute for E-Learning, 2017; Hsu, 2010; Markauskaite, 2007; Virginia Öğretim Personeli Teknoloji Standartları, 1998).

BİT'in yaşamın her alanına hızlıca girmesi, eğitimin niteliğine ilişkin umut verici çıktıları ve eğitime entegrasyonu için gerçekleştirilen büyük bütçeli projeler göz önünde bulundurulduğunda, öğretmen yetiştiren kurumlardan BİT yeterliklerine sahip öğretmen adayları yetiştirmeleri beklenmektedir. Bu beklentinin gerçekleşip gerçekleşmediğini belirlemek için ise öğretmen adaylarının yeterliklerinin belirlenebilmesi gerekmektedir (Tondeur ve diğerleri, 2017). Ulusal alanyazın incelendiğinde, öğretmenlerin veya öğretmen adaylarının BİT yeterliklerini ölçmeye yönelik çeşitli araçların bulunduğu görülmektedir. Örneğin, Şad ve Nalçacı (2015) öğretmen adaylarının eğitimde bilgi ve iletişim teknolojilerini kullanmaya ilişkin yeterlik algılarını belirlemeyi amaçladıkları çalışmalarında 30 maddelik bir ölçme aracı geliştirmiştir. Öğretmenlik Mesleği Genel Yeterlikleri (MEB, 2006) temel alınarak geliştirilen ölçek tek faktörden oluşmaktadır. Geliştirilen ölçme aracı detaylı olarak incelendiğinde, ölçek maddelerinin genellikle çeşitli aygıt veya yazılımların sınıf içerisinde kullanılmasına ve BİT ile ilgili bilgi düzeyine odaklandığı görülmektedir. Benzer bir ölçme aracı Şimşek ve Yazar (2016) tarafindan Uluslararası Eğitim Teknolojisi Standartları (ISTE, 2014) temel alınarak geliştirilmiştir. Toplam 40 
maddeden oluşan ölçek, öğrencilerin öğrenmelerini kolaylaştırma ve yaratıcılığı teşvik etme, dijital çağa uygun öğrenme ortamları ve değerlendirme etkinlikleri tasarımlama ve geliştirme, dijital çağın çalışma ve öğrenme anlayışına öncülük etme, dijital vatandaşlıkta model olma ve mesleki gelişim ve liderlik etkinliklerine katılma olmak üzere beş faktörden oluşmaktadır.

Sözü edilen ölçeklerin bazı dezavantajları bulunmaktadır. Öncelikle her iki veri toplama aracı da tek bir kuramsal çerçeve temel alınarak geliştirilmiştir. Şad ve Nalçacı (2015) tarafından geliştirilen ölçek Öğretmenlik Mesleği Genel Yeterliklerini (MEB, 2006) temel alırken Şimşek ve Yazar (2016) tarafından geliştirilen ölçek ise Uluslararası Eğitim Teknolojileri Standartlarını (ISTE, 2014) temel almıştır. Öte yandan mevcut çalışmada Türk kültürüne uyarlanması amaçlanan Öğretmen Adayları için Bilgi ve İletişim Teknolojileri Yeterlikleri Ölçeği (Tondeur ve diğerleri, 2017) ise, aralarında Virginia Öğretim Personeli Teknoloji Standartları (1998), Öğretmenler için BİT yeterlik standartları ve çerçevesi (UNESCO, 2008) ve Öğretmenler ve Eğiticiler için E-Öğrenme Yeterlik Çerçevesi’nin (European Institute for E-Learning, 2017) de bulunduğu toplam 20'nin üzerinde yeterlik çerçevesi incelenerek ortaya konmuştur. Temel alınan kuramsal altyapılar göz önünde bulundurulduğunda, uyarlaması yapılan ölçeğin, diğer ölçeklere kıyasla daha bütüncül bir bakış açısıyla geliştirildiği söylenebilir. Bu duruma ek olarak, uyarlaması gerçekleştirilen ölçeğin diğer ölçeklere göre daha kısa oluşu, ikinci bir avantaj olarak görülmektedir çünkü kısa veri toplama araçlarının bir tercih sebebi olduğu ve uygulamada kolaylık sağladığı bilinmektedir (Morin, Scalas, Vispoel, Marsh, \& Wen, 2016). Bu bağlamda Şad ve Nalçacı (2015) tarafindan geliştirilen ölçek 30 madde, Şimşek ve Yazar (2016) tarafindan geliştirilen ölçek ise 40 maddeden oluşurken bu çalışmada uyarlaması amaçlanan ölçek 19 maddeden oluşmaktadır. Bu noktalardan hareketle bu çalışmada Tondeur, Aesaert, Pynoo, Braak, Fraeyman ve Erstad (2017) tarafından geliştirilmiş olan "Öğretmen Adayları için BİT Yeterlikleri Ölçeğinin” Türk dili ve kültürüne uyarlanması amaçlanmıştır.

\section{Yöntem}

Bu bölümde katılımcılar, veri toplama araçları, veri toplama süreci, işlemler ve veri analizine ilişkin bilgiler başliklar halinde verilmektedir.

\section{Katılımcılar}

Bu araştırma, 2017-2018 Eğitim Öğretim Yılı Güz Yarıyılında Gaziosmanpaşa Üniversitesi Eğitim Fakültesi'nin çeşitli bölümlerinde öğrenim görmekte olan toplam 206 (163 Kadın, 43 Erkek) öğretmen adayı üzerinde yürütülmüştür. Katılımcıların yaşı 18 ile 25 arasında değişmektedir ve yaş ortalamaları 20.50’dir (SS=1.13). 43 katılımcı (\%21) Sosyal Bilgiler Öğretmenliği, 68 katılımcı (\%33) Fen Bilgisi Öğretmenliği ve 95 katılımcı (\%46) Sınıf Öğretmenliği programlarında öğrenim görmektedir. 69 katılımcı (\%34) ikinci sınıf öğrencisiyken 137 (\%66) katılımcı ise üçüncü sınıf öğrencisidir.

Orijinal ölçeğin (Tondeur ve diğerleri, 2017) geliştirilme basamaklarında önerildiği üzere, katılımcıların seçiminde ölçüt olarak, katılımcıların eğitim fakültesinde öğrenim görmekte olan öğretmen adayı olmaları göz önünde bulundurulmuştur. Ayrıca çalışmanın daha hızlı ve verimli gerçekleşebilmesi için katılımcılar araştırmacıların çalıştıkları Eğitim Fakültesi’nde öğrenim gören ve araştırmaya katılmaya gönüllü olan öğrenciler olarak belirlenmiştir. Bu bağlamda kolay ulaşılabilir örnekleme yöntemi kullanılmıştır.

$\mathrm{Bu}$ çalışmada katılımcı sayısının doğrulayıcı faktör analizi için uygunluğunu belirlemek için çeşitli ölçütler göz önünde bulundurulmuştur. Wolf, Harrington, Clark ve Miller (2013) gerçekleştirdikleri simülasyon çalışmasında 2 faktörlü ve 8 'den fazla gösterge içeren modellerde en az 150 katılımcıdan veri toplanmasının doğrulayıcı faktör analizi için yeterli olduğunu göstermişlerdir. Benzer şekilde Kline (2016) doğrulayıcı faktör analizi için genel kabul gören minimim örneklem sayısının 200 olduğunu belirtmektedir. Çalışmada 206 katılımcıdan veri toplanarak doğrulayıcı faktör analizi gerçekleştirilmiştir.

\section{Veri Toplama Araçları}

Bu çalışmanın verileri Öğretmen Adayları için BİT Yeterlikleri Ölçeği kullanılarak elde edilmiştir. Bu veri toplama aracına ek olarak, yakınsak geçerliği sınamak için Bilgi ve İletişim Teknolojilerine Yönelik Tutum Ölçeğinin Genel BİT Eğilimi isimli alt boyutu kullanılmıştır. Yakınsak geçerlik, kuramsal olarak benzer yapıların ölçümleri arasında güçlü ilişkilerin belirlenmesi ile sağlanır (Brown, 2006). Bu bağlamda BİT yeterlikleri ile Genel BİT Eğilimi alt boyutu kuramsal olarak benzer yapıda olduğu için Genel Bit Eğilimi boyutu kullanılmıştır. Ayırt edici geçerlik, Gerçeklik Şoku Beklentisi Ölçeği kullanılarak 
sınanmıştır. Bu geçerlik türü yakınsak geçerliğin tam tersi bir şekilde, kuramsal olarak farklı yapıların ölçümleri arasında güçlü ilişkilerin olmaması ile belirlenir (Brown, 2006). Dolayısıyla, Gerçeklik Şoku Beklentisi ile BİT Yeterlikleri kuramsal olarak ilişkili yapılar olmadığı için Gerçeklik Şoku Beklentisi Ölçeği kullanılmıştır. Son olarak eş zamanlı geçerlik için ise Öğretmen Adaylarının Eğitimde Bilgi ve İletişim Teknolojilerini Kullanmaya İlişkin Yeterlilik Algıları Ölçeğinden yararlanılmıştır. Eşzamanlı geçerlik, aynı değişkeni ölçmeyi amaçlayan yeni bir ölçek ile bu yapıyı ölçtüğü daha önceden belirlenmiş bir ölçekten alınan puanlar arasındaki ilişkinin varlığı ile belirlenir (Gravetter \& Forzano, 2012). Dolayısıyla bu çalışmada uyarlanan ölçek ile Öğretmen Adaylarının Eğitimde Bilgi ve İletişim Teknolojilerini Kullanmaya İlişkin Yeterlilik Algıları Ölçeği aynı anda uygulanarak eşzamanlı geçerliğe yönelik kanıt aranmıştır.

Öğretmen adaylart için BITT yeterlikleri ölçeği. Orijinal dili İngilizce olan bu veri toplama aracı Tondeur, Aesaert, Pynoo, Braak, Fraeyman ve Erstad (2017) tarafından geliştirilmiş öz bildirim türünde bir ölçme aracıdır. Öğretmen Adayları için BİT Yeterlikleri Ölçeği’nin orijinal formunun geliştirilmesi aşamasında öncelikle alanyazın taraması sonrası madde havuzu oluşturulmuş ve bu madde havuzu ilgili paydaşların (öğretmen adayları, öğretmen eğiticileri, BİT koordinatörleri ve araştırmacılar) görüşüne sunulmuştur. Paydaşlarla gerçekleştirilen görüş alışverişi üzerine 5'li Likert tipi (1=Kesinlikle Katılmiyorum, 5=Kesinlikle Katılıorum) bir derecelendirmeye sahip olan 19 maddelik bir form elde edilmiştir. Daha sonra Belçika'da bulunan öğretmen yetiştirme enstitüleri ile iletişime geçilmiş ve katılım konusunda gönüllü olan 20 kuruma veri toplama aracı çevrimiçi anket şeklinde gönderilmiştir. Süreç sonunda 931 öğretmen adayı formu doldurarak çalışmaya katılmıştır. Elde edilen veriler rastgele bir şekilde ikiye ayrılmıştır. Yapı geçerliğini test etmek için verilerin yarısı üzerinde açımlayıcı faktör analizi, diğer yarısı üzerinde ise doğrulayıcı faktör analizi gerçekleştirilmiştir. Açımlayıcı faktör analizi ortaya iki faktörlü bir yapı koymuştur. Bu yapı ortak varyansın \%56.3'ünü açıklamıştır. Ölçek maddelerine ait faktör yükleri 0.57 ile 0.85 arasında değişmiştir. 11 maddeden oluşan birinci faktöre Öğrencilerin BİT Kullanımlarını Destekleme Konusunda BİT Yeterlikleri adı verilmiştir. Bu faktör öğretmen adaylarının öğrenme süreçlerinde öğrencilerini BİT kullanımı konusunda eğitmeye yönelik olarak kendilerini ne ölçüde yeterli hissettiklerini/gördüklerini ölçmeyi amaçlamaktadır. Örneğin, "öğrencileri, bilgi ve iletişim teknolojileri kullanarak birlikte çalışmaları konusunda destekleyebilirim" bu boyutta yer alan maddelerden bir tanesidir. 8 maddeden oluşan ikinci faktöre ise Öğretim Tasarımına Yönelik BİT Yeterlikleri adı verilmiştir. Bu faktör öğretmen adaylarının öğretim uygulamalarını destekleme ve güçlendirme açısından BİT kullanımı noktasında kendilerini ne ölçüde yeterli hissettiklerini/gördüklerini ölçmeyi amaçlamaktadır. Örneğin, "öğrencilerin öğrenme sürecini dijital ortam kullanarak takip edebilirim” ifadesi bu boyutta yer alan maddelerden biridir. Öne sürülen iki faktörlü yapının doğrulanıp doğrulanmadığını test etmek için verilerin diğer yarısı üzerinde doğrulayıcı faktör analizi gerçekleştirilmiştir. Elde edilen uyum endeksleri $(\mathrm{GFI}=0.91 ; \mathrm{AGFI}=0.88 ; \mathrm{TLI}=0.95 ; \mathrm{CFI}=0.96$; $\mathrm{RMSEA}=0.06)$ ve maddelere ait faktör yüklerinin 0.65 ile 0.84 arasında değişmesini göz önünde bulundurarak yazarlar iki faktörlü yapının doğrulandığı sonucuna varmıştır. Ayrıca aynı faktör içerisinde benzer noktaları ölçtüğü görüldüğü için madde 3 ve 4 ile madde 15 ve 16 arasındaki hata varyanslarının ilişki kurmasına izin verilmiştir. Son olarak, ölçekte yer alan faktörlerin güvenirlik analizi Cronbach alfa iç tutarlılık katsayıları hesaplanarak gerçekleştirilmiştir. Sonuçlara göre birinci faktör $(\alpha=0.94)$ ve ikinci faktörden $(\alpha=0.89)$ elde edilen iç tutarlılık katsayıları, faktör maddelerinden elde edilen değerlerin iç tutarlılığa sahip olduğunu göstermiştir. Ölçek boyutlarından alınan yüksek puanlar, ilgili boyuta ilişkin katılımcının kendi yeterli olarak algıladığını gösterirken boyutlardan alınan düşük puanlar katılımcının ilgili boyutta kendini yetersiz olarak algıladığını göstermektedir (Tondeur ve diğerleri, 2017).

Bilgi ve iletişim teknolojilerine yönelik tutum ölçeği. Bu veri toplama aracı Günbatar (2014) tarafindan geliştirilmiştir. Ölçek 5'li Likert tipi (1=Hiç Katılmıyorum, 5=Tamamen Katılıyorum) derecelendirmeye sahiptir. Yazarlar, toplam 381 lisans öğrencisi ile yürüttükleri araştırmada elde edilen veriler üzerinde açımlayıcı ve doğrulayıcı faktör analizi gerçekleştirmiştir. Açımlayıcı faktör analizi sonucunda ilk olarak 10 faktör ve 54 maddeden oluşan bir yapı elde edilmiş, birden fazla faktörde yük alan ve ölçeğin yapısına uymayan maddelerin çıkarılması ile ölçek son halini almıştır. Bu işlem sonrası 23 madde ve 5 faktörden oluşan ölçeğin maddelerinin faktör yükleri 0.60 ile 0.89 arasında değişmiştir. Doğrulayıcı faktör analizi sonucuna göre ise elde edilen modelin doğrulandığı görülmüştür (RMSEA =0.058; NFI =0.96; NNFI = 0.97; CFI = 0.98; IFI = 0.98; GFI = 0.90; AGFI =0.87). Ölçeğin güvenirliği Cronbach alfa iç tutarlılık ve test tekrar test güvenirlik katsayıları ile incelenmiştir. İç tutarlılık katsayıları 0.76 ile 0.92 arasında 
değişmiştir. Test tekrar test güvenirlik katsayıları ise 0.71 ile 0.93 arasında değişmiştir. Bu çalışmada ise ilgili ölçeğin 6 maddeden oluşan ve Genel BİT Eğilimi olarak adlandırılan boyutu kullanılmıştır. Genel BİT Eğilimi boyutu, bireylerin BİT kullanımına yönelik tutumları ölçmeyi amaçlamaktadır. 'BİT'i güncel hayatta kullanmayı seviyorum" ifadesi, bu boyuttaki maddelerden biridir. Orijinal çalışmada Genel BİT Eğilimi boyutuna ilişkin iç tutarlılık katsayısı 0.89 ve test tekrar test güvenirlik katsayısı 0.90 olarak hesaplanmıştır (Günbatar, 2014). Bu çalışmada ise Genel BİT Eğilimi alt boyutunun iç tutarlılık katsayısı .87 olarak elde edilmiştir.

Gerçeklik şoku beklentisi ölçeği. Gerçeklik Şoku Beklentisi Ölçeği Kim ve Cho (2014) tarafindan geliştirilmiş ve Özdemir ve Büyükgöze (2016) tarafından Türk kültürüne uyarlanmıştır. 7’li Likert tipi (1=Hiç Doğru Değil, 7=Çok Doğru) derecelendirmeye sahip olan ölçek 9 madde ve tek faktörden oluşmaktadır. Ölçek, öğretmen adaylarının, mesleklerinin ilk yılına ilişkin gerçeklik şoku beklentilerini belirlemeyi amaçlamaktadır. "Sınıf yönetimi, uygulamada öğretmenlere öğretilen teorilerden farklı olacaktır” ifadesi, ölçek maddelerinden biridir. Katılımcıların ölçekten yüksek puan alması, gerçeklik şoku beklentisinin fazla olduğunu göstermektedir. Ölçeğin uyarlama çalışması 120 öğretmen adayından elde edilen veriler üzerinde gerçekleştirilmiştir. Bu kapsamda gerçekleştirilen doğrulayıcı faktör analizi, orijinal çalışmasında keşfedilmiş olan tek faktör yapısının doğrulandığını göstermiştir, AGFI = 0.86; GFI = 0.92; $\mathrm{NFI}=0.89 ; \mathrm{CFI}=0.94 ; \mathrm{IFI}=0.84 ; \mathrm{SRMR}=0.16$; RMSEA = 0.08 (Özdemir \& Büyükgöze, 2016). Ayrıca ölçeğin Cronbach alfa iç tutarlılık katsayısı orijinal çalışmada 0.88 (Kim \& Cho, 2014); uyarlama çalışmasında 0.78 (Özdemir \& Büyükgöze, 2016); bu çalışmada ise 0.82 olarak bulunmuştur.

Eğitimde bilgi ve iletişim teknolojilerini kullanmaya ilişkin yeterlilik algıları ölçeği. Bu veri toplama aracı MEB tarafından belirlenen 6 ana, 31 alt yeterlik alanı ve 233 performans göstergesinden oluşan Öğretmenlik Mesleği Genel Yeterlikleri temel alınarak Şad ve Nalçacı (2015) tarafından geliştirilmiştir. Ölçek, öğretmenlerin BİT yeterlik algılarını belirlemeyi amaçlamaktadır. "Ders materyallerimi akıllı tahta, projektör, tepegöz vb. gibi araçlarla sunabilme" ifadesi, ölçekte yer alan maddelerden biridir. 5'li Likert (1=Oldukça Yetersizim, 5=Oldukça Yeterliyim) derecelendirmeye sahip olan ölçek toplam 30 madde ve tek faktörden oluşmaktadır. Toplam 409 öğretmen adayı ile yürüttükleri araştırmada elde edilen veriler üzerinde açımlayıcı faktör analizi gerçekleştiren araştırmacılar ortak varyansın \%48'inin açıklandığını ifade etmişlerdir. Ayrıca maddelere ait faktör yüklerinin 0.52 ile 0.76 arasında değiştiği, ölçeğe ait Cronbach alfa iç tutarlılık katsayısı 0.96 ve Guttman iki yarı tutarlılık katsayısının 0.93 olduğu bulunmuştur (Şad \& Nalçac1, 2015). Bu çalışmada ise Cronbach alfa iç tutarlılık katsayısı .95 olarak bulunmuştur.

\section{Veri Toplama Süreci}

Bu araştırmanın verileri 2017-2018 eğitim öğretim yılı güz döneminde Gaziosmanpaşa Üniversitesi Eğitim Fakültesi'nde öğrenim görmekte olan toplam 206 öğretmen adayından toplanmıştır. Veri toplama işlemi, sınıf ortamında araştırmacılar tarafından gerçekleştirilmiştir. Öğrencilere çalışmanın amacı ve kendilerinden beklentiler açıklanmış, gönüllü olanlara form dağıtılarak veriler toplanmıştır.

\section{İşlemler ve Verilerin Analizi}

Öğretmen Adayları için BİT Yeterlikleri Ölçeğinin Türk kültürüne uyarlama süreci Borsa, Damásio ve Bandeira'nın (2012) ölçek uyarlama sürecine yönelik önerilerinden yararlanılarak gerçekleştirilmiştir. Buna göre çalışmada uygulanan işlemler, (1) çeviri süreci, (2) çevirilerin sentezlenmesi, (3) uzman görüşü alınması ve (4) hedef kitlenin görüşünün alınmasıdır (Borsa, Damásio, \& Bandeira, 2012). Bu çalışmada ölçeğin uyarlanması sürecinde anlamın korunmasına önem verildiği ve geri-çeviri sürecinin anlam ve bağlam kaybına yol açabileceği endişesiyle geri-çeviri yöntemi uygulanmamıştır (Gudmundsson, 2009).

Borsa, Damásio ve Bandeira'nın (2012) ölçek uyarlama önerileri bağlamında, öncelikle Öğretmen Adayları için BITT Yeterlikleri Ölçeğinin İngilizce orijinal formunu geliştiren Dr. Jo Tondeur ile e-posta yoluyla iletişime geçilmiş ve ölçeğin uyarlanabileceğine ilişkin izin alınmıştır. İzin işleminden sonra (1) ölçek maddeleri iyi düzeyde İngilizce bilen ve İngilizce öğretmenliği programından mezun olmuş üç çevirmen tarafından Türkçeye çevrilmiştir. (2) Elde edilen çeviriler ileri düzeyde İngilizce bilen araştırmacılar tarafından incelenmiş ve her bir madde için, üç çevirmenden en az ikisi tarafindan benzer şekilde çevrilen ve o maddeyi en iyi şekilde temsil ettiği düşünülen Türkçe ifadeler belirlenmiştir. (3) Elde edilen Türkçe maddeler kullanılarak uzman görüşü formu hazırlanmıştır. $\mathrm{Bu}$ formda yer alan ölçek maddeleri iki Türkçe dil uzmanına ve iki bilgisayar ve öğretim teknolojileri alan uzmanına sunulmuştur. 
Bu uzmanlardan alınan dönütler üzerine noktalama, kelime seçimi ve dilbilgisi konularında dört madde üzerinde düzeltmeler yapılmıştır. (4) Daha sonra altı öğretmen adayı ile gerçekleştirilen odak grup görüşmesinde katılımcıların ölçek maddelerine ilişkin görüşleri alınmıştır. Bu aşamada katılımcı görüşleri temelinde maddelerin ifade edilişine ilişkin olarak anlam ve anlaşılırlığı geliştirmek üzere iki maddede ve yönerge üzerinde değişiklikler yapılmıştır. Uzman görüşleri ve odak grup görüşmeleri neticesinde son hali verilen ölçeğin Türkçe formu ile orijinal İngilizce formu araştırmacılar tarafından tekrar incelenerek iki formun iki formun dilsel eşdeğerliğe sahip olduğu görülmüştür.

Daha önceden geliştirilmiş faktör yapısı bilinen bir ölçeğin yeni bir örneklemden veri toplanarak faktör yapısının test edilmesini amaçlayan çalışmalarda doğrulayıcı faktör analizinin gerçekleştirilmesi önerilmektedir (Kline, 2016; Tabachnick \& Fidell, 2013). Bu bağlamda, bu çalışmada Türkçeye uyarlanan Öğretmen Adayları için BİT Yeterlikleri Ölçeğinin faktör yapısının ölçeğin orijinal İngilizce formunda önerilen faktör yapısı ile uyumunun test edilmesi amacıyla doğrulayıcı faktör analizi gerçekleştirilmiştir. Çalışmada ayrıca yakınsak, ayırt edici ve eşzamanlı geçerlik çalışmaları gerçekleştirilmiştir. Güvenirlik çalışması için Cronbach alfa iç tutarlılık katsayısı hesaplanmıştır. Sözü edilen tüm bu analizler, SPSS 20, AMOS 24 ve Mplus 6.12 yazılımları ile gerçekleştirilmiştir. Bu çalışmada alfa değeri .05 olarak belirlenmiştir.

\section{Bulgular}

\section{Betimsel İstatistikler}

Öğretmen Adayları için BİT Yeterlikleri Ölçeğinin toplam puan, altboyutlar ve maddelerine yönelik aritmetik ortalama, standart sapma, minimum ve maksimum değerleri ile çarpıklık ve basıklık katsayıları Tablo 1'de sunulmaktadır. Ölçekten alınan ortalama puanların nötr değer alt limiti olan 2.5 'den düşük olması ilgili boyuta ilişkin olarak katılımcıların kendilerini yetersiz olarak algıladığını gösterirken, ortalama puanların nötr değer üst limiti olan 3.5 'den yüksek olması ise katılımcıların kendilerini yeterli olarak algıladığını göstermektedir. Madde bazında aritmetik ortalama değerlerine bakıldığında, aritmetik ortalamaların çoğunlukla (madde 13: "Belirli bir eğitim ortamını dikkate alarak, Bilgi ve İletişim Teknolojileri uygulamalarını (yeniden) tasarlayabilirim." maddesi dışında) nötr değer üst limiti olan 3.5'den yüksek olduğu görülmektedir. Benzer şekilde Öğretmen Adayları için BİT Yeterlikleri Ölçeğinin altboyutlarına ve toplam puanına ait aritmetik ortalama değerleri de 3.5'den yüksektir. Buna göre, araştırmaya katılan öğretmen adayları öğrencilerin BİT kullanımlarını destekleme konusunda, Öğretim Tasarımına Yönelik BİT Yeterlikleri konusunda ve genel olarak BİT kullanımı konusunda kendilerini yeterli hissetmektedirler.

Tablo 1. Ortalama, Standart Sapma, Minimum ve Maksimum Değerler, Çarpıklık ve Basıklık Değerleri

\begin{tabular}{lcccccc}
\hline Boyut ve Maddeler & Ort. & SS & Min. Puan & Maks. Puan & Çarpıklık & Basıklık \\
\hline BİT Kul. Des. & 4.08 & .60 & 1.45 & 5.00 & -1.60 & 4.79
\end{tabular}




\begin{tabular}{|c|c|c|c|c|c|c|}
\hline Öğr. Tas. BİT & 3.87 & .59 & 1.50 & 5.00 & -.93 & 1.91 \\
\hline BİT Ölçeği Toplam & 3.99 & .55 & 1.58 & 5.00 & -1.38 & 4.30 \\
\hline Madde 1 & 4.15 & .81 & 1 & 5 & -1.45 & 3.41 \\
\hline Madde 2 & 3.86 & .88 & 1 & 5 & -.94 & 1.11 \\
\hline Madde 3 & 4.14 & .72 & 1 & 5 & -.98 & 2.07 \\
\hline Madde 4 & 4.09 & .82 & 1 & 5 & -1.33 & 2.94 \\
\hline Madde 5 & 4.02 & .81 & 1 & 5 & -1.02 & 1.86 \\
\hline Madde 6 & 4.21 & .81 & 1 & 5 & -1.35 & 2.87 \\
\hline Madde 7 & 4.02 & .83 & 1 & 5 & -1.21 & 2.66 \\
\hline Madde 8 & 4.17 & .77 & 1 & 5 & -1.38 & 3.54 \\
\hline Madde 9 & 4.06 & .88 & 1 & 5 & -1.10 & 1.63 \\
\hline Madde 10 & 4.11 & .85 & 1 & 5 & -1.12 & 1.77 \\
\hline Madde 11 & 4.00 & .91 & 1 & 5 & -1.01 & 1.15 \\
\hline Madde 12 & 4.00 & .74 & 2 & 5 & -.69 & .68 \\
\hline Madde 13 & 3.46 & .96 & 1 & 5 & -.22 & -.27 \\
\hline Madde 14 & 4.10 & .79 & 1 & 5 & -1.31 & 3.36 \\
\hline Madde 15 & 3.87 & 1.03 & 1 & 5 & -.89 & .46 \\
\hline Madde 16 & 3.99 & .90 & 1 & 5 & -.83 & .67 \\
\hline Madde 17 & 4.08 & .84 & 1 & 5 & -1.12 & 1.81 \\
\hline Madde 18 & 3.69 & .95 & 1 & 5 & -.57 & .14 \\
\hline Madde 19 & 3.82 & .81 & 1 & 5 & -.47 & .47 \\
\hline
\end{tabular}

Not: BİT Kul. Des: Öğrencilerin BİT Kullanımlarını Destekleme Konusunda BİT Yeterlikleri, Öğr. Tas. BITT: Öğretim Tasarımına Yönelik BİT Yeterlikleri

\section{Doğrulayıcı Faktör Analizine İlişkin Bulgular}

Öğretmen Adayları için BİT Yeterlikleri Ölçeği'nin orijinal yapısının Türkçe formda da sağlanıp sağlanmadığını belirlemek için doğrulayıcı faktör analizi (DFA) gerçekleştirilmiştir. $\mathrm{Bu}$ analizi gerçekleştirmeden önce doğrulayıcı faktör analizinin varsayımları olan uç değerler, tek değişkenli ve çok değişkenli normallik ve çoklu doğrusal bağlantı (multicollinearity) kontrol edilmiştir (Flora, LaBrish, \& Chalmers, 2012).

Uç değerler. Öncelikle DFA çok değişkenli bir analiz olduğu için, çok değişkenli uç değerler incelenmiştir. Bunun için Mahalanobis mesafesi kullanılmıştır. Mahalanobis mesafesi için olasılık değeri $\mathrm{p}<.001$ ölçütünün altında olan 10 katılımcının verdiği yanıtlar uç değer olarak belirlenmiş̧tir (Tabachnick \& Fidell, 2013). Bunun üzerine DFA hem uç değerler çıkarılmış hem de çıkarılmamış veri üzerinde gerçekleştirilmiştir. İki analiz sonuçları arasında herhangi bir farklılık olmadığı için uç değerler çıkarılmadan analizlere devam edilmiştir.

Tek değişkenli ve çok değisşkenli normallik. Tek değişkenli normallik için madde bazında çarpıklık ve basıklık katsayıları ile Q-Q grafikleri incelenmiştir. Çarpıklık ve basıklık katsayıları sıfır olduğu zaman dağılımın mükemmel bir şekilde normal olduğu söylenebilir (Tabachnick \& Fidell, 2013). Çarpıklık katsayısının 3'ten, basıklık katsayısının ise 10'dan büyük olması dağılımın normal olmadığını gösterir (Kline, 2016). Ölçek maddelerinin çarpıklık katsayısının \pm 2 ve basıklık katsayısının \pm 4 aralığında olması, tek değişkenli normal dağılımı işaret etmektedir. Ayrıca Q-Q grafiklerinde de verilerin 45 derecelik bir 
çizgi üzerinde dağıldığı görülmüştür. Bu bulgu da normal dağılımı işaret eden diğer bir parametredir (Tabachnick \& Fidell, 2013). Çok değişkenli normallik için Mardia testi AMOS yazılımı aracılığıyla kullanılmıştır. Bu test sonucunda elde edilen çok değişkenli basıklık değeri 1'in altında ise ihmal edilebilir anormalliği; 1-10 arasında ise orta düzey anormalliği ve 10'un üzerinde ise ciddi düzeyde anormalliği ifade eder (Shen, Schüttemeyer, \& Braun, 2009). Ayrıca eğer kritik oran 1.96'nın altındaysa, verilerin .05 anlamlılık düzeyinde çoklu normal dağılım sergilediği düşünülebilir (Mardia, 1970). Sonuçlara göre çok değişkenli basıklık değeri 147.72 ve kritik oran ise 37.52 olarak belirlendiği için verilerin çok değişkenli normallik varsayımını karşılamadığı görülmüştür.

Çoklu doğrusal bağlantı (Multicollinearity). Maddeler arasında çoklu doğrusal bağlantı durumunu belirlemek için maddeler arası korelasyon değerleri hesaplanmıştır. Bu analize göre maddeler arasındaki korelasyon değerleri .13 ile .66 arasında değişmiştir. Ayrıca iki faktör arasındaki tahmin edilen korelasyon değeri ise .80 olarak hesaplanmıştır. Elde edilen değerler Kline (2016) tarafindan önerilen eşik değer olan .90 ’’n altında olduğu için verilerin çoklu doğrusal bağlantı sorununa sahip olmadığı ve varsayımı sağladığı sonucuna varılmıştır.

Model иуити. DFA varsayımlarının incelenmesi üzerine verilerin çok değişkenli normalliği sağlamadığı görülmüştür. Dolayısıyla DFA, MPlus yazılımı kullanılarak standart hatalara dirençli olan maksimum olabilirlik hesaplaması yöntemi (Maximum Likelihood Robust, MLR) ile gerçekleştirilmiştir. MLR yöntemi çok değişkenli normalliği gerektirmeyen yapısal eşitlik modellemesinde kullanılan bir hesaplama yöntemidir (Muthen \& Muthen, 2007). Modelin uyumunu değerlendirmek için MacCallum, Browne ve Sugawara (1996) tarafından önerilen Ki-kare/serbestlik derecesi oranı, karşılaştırmalı uyum endeksi (CFI), yaklaşık hataların ortalama karekökü (RMSEA) ve standartlaştırılmış hata kareleri ortalamasının karekökü (SRMR) ile Brown (2006) tarafından önerilen Tucker Lewis Endeksi (TLI) incelenmiştir.

Buna göre, $\chi^{2}(149)=235.962, p<.05$ olarak bulunmuştur. $\mathrm{Bu}$ değerin anlamlı çıkması modelin reddedilmesi anlamına gelmesine rağmen (Dilalla, 2000) ki-kare değerinin korelasyonlara ve örneklem büyüklüğüne karşı hassas olması, model uyumuna karar verirken bu değerin tek başına bir uyum istatistiği olarak ele alınması noktasında temkinli olmayı gerektirir (Kline, 2016). Diğer değerler, $\chi^{2} / \mathrm{sd}=1.58$, CFI= $.93, \mathrm{RMSEA}=.05$ (\%90 Güven aralı̆̆ $=.040-.066)$, SRMR= .05 şeklindedir. Sonuçlar modelin beklenen faktör yapısına uyum gösterdiğini ortaya koymaktadır (Kline, 2016). Tablo 2'de görüldüğü üzere, elde edilen uyum endeksi değerleri kabul edilebilir sınırlar içerisinde yer almaktadır ve özgün ölçeğin geliştirilmesi aşamasında elde edilen değerlere yakındır.

Tablo 2. Uyum Endeksleri Değerleri

\begin{tabular}{lccl}
\hline Endeks & Özgün Ölçek & Türkçe Ölçek & Kabul Edilebilir Eşik Değerler \\
\hline $\mathrm{X}^{2} / \mathrm{df}$ & - & 1.58 & $\leq 5$ (Bollen, 1989) \\
CFI & .96 & .93 & $\geq .90$ (Marsh, Hau, \& Wen, 2004) \\
TLI & .95 & .92 & $\geq .90$ (Baumgartner \& Homburg, 1996) \\
RMSEA & .06 & .05 & $\leq .08$ (MacCallum, Browne, \& Sugawara, 1996) \\
SRMR & - & .05 & $\leq .08$ (Kline, 2016) \\
\hline
\end{tabular}

Alt boyutlar için faktör yükleri incelendiğinde Öğrencilerin BİT Kullanımlarını Destekleme Konusunda BİT Yeterlikleri alt boyutu için faktör yüklerinin .53 ile .78 arasında, Öğretim Tasarımına Yönelik BİT Yeterlikleri alt boyutu için .44 ile .74 arasında değiştiği bulunmuştur. Böylece faktör yüklerinin .30’un üstünde olduğu ve maddelerin kuramsal olarak yüklenmeleri beklenen faktöre yüklendikleri görülmüştür (Hair, Black, Babin, Anderson, \& Tatham, 2006). Modele ilişskin faktör yükleri ve standart hata değerleri Şekil 1'de görülebilir. 


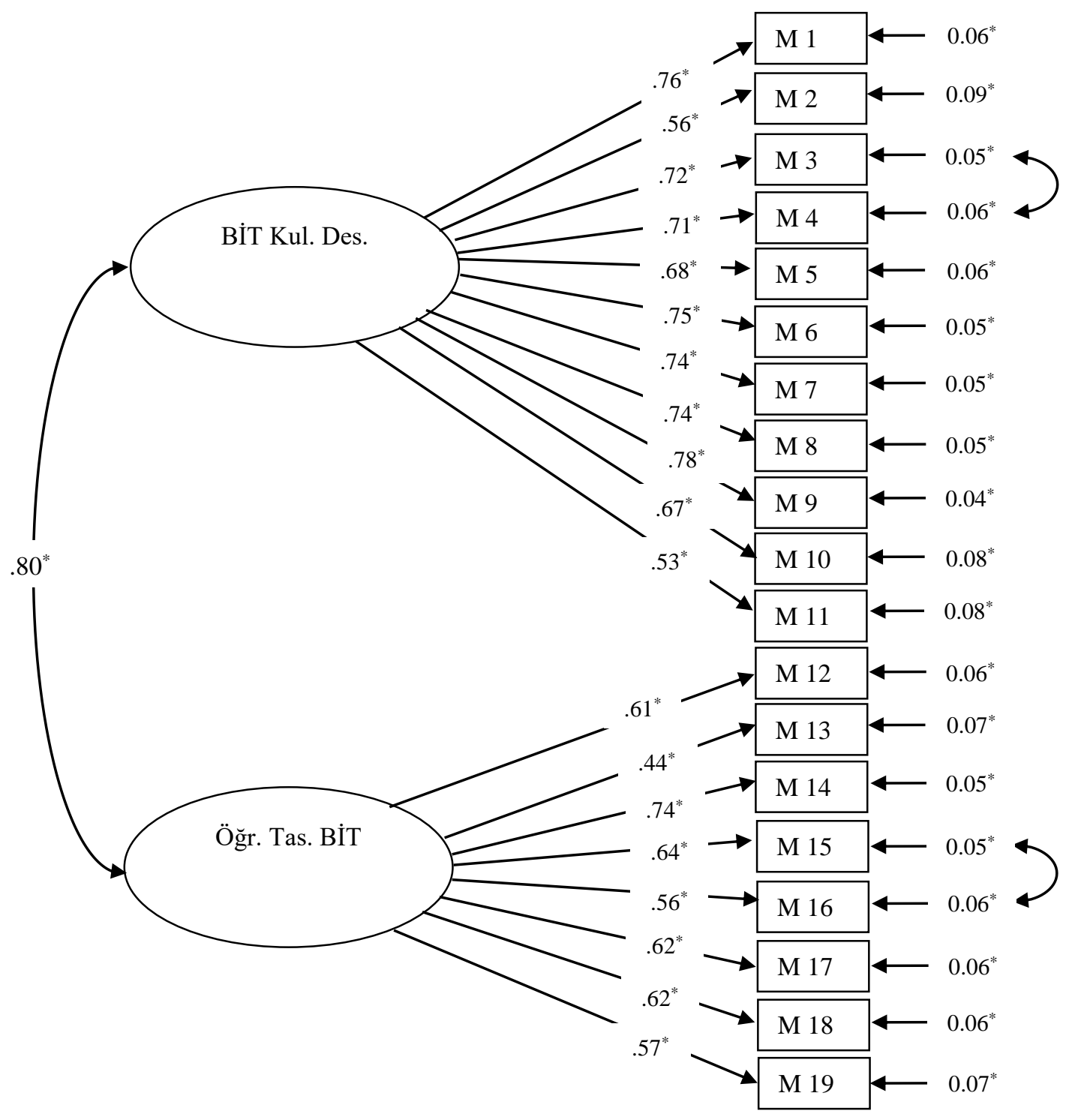

Şekil 1. Faktör Yükleri ve Standart Hatalar

Not: " $p<.05$, M1-M19: Ölçek maddeleri, BİT Kul. Des: Öğrencilerin BİT Kullanımlarını Destekleme Konusunda BİT Yeterlikleri, Öğr. Tas. BİT: Öğretim Tasarımına Yönelik BİT Yeterlikleri

\section{Yakınsak, Ayırt Edici ve Eş Zamanlı Geçerliğe İlişsin Bulgular}

Yakınsak, ayırt edici ve eş zamanlı geçerliğin test edilmesi için farklı ölçekler ile Öğretmen Adayları için BİT Yeterlikleri ölçeğinin boyutları arasındaki Pearson korelasyon katsayıları incelenmiştir. Buna göre, Öğrencilerin BİT Kullanımlarını Destekleme Konusunda BİT Yeterlikleri alt ölçeğinden alınan puanlar ile Genel Bit Eğilimi $(r(206)=0.51, p<.05)$ ve Eğitimde Bilgi ve İletişim Teknolojilerini Kullanmaya İlişkin Yeterlilik Algıları Ölçeğinden $(r(206)=0.48, p<.05)$ alınan puanlar arasında pozitif yönde istatistiksel olarak anlamlı ilişkiler bulunurken Gerçeklik Şoku Beklentisi Ölçeğinden $(r(206)=$ $0.11, p>.05)$ alınan puanlar arasında istatistiksel olarak anlamlı ilişki saptanmamıştır. Benzer şekilde, Öğretim Tasarımına Yönelik BİT Yeterlikleri alt ölçeğinden alınan puanlar ile Genel Bit Eğilimi $(r(206)$ $=0.56, p<.05)$ ve Eğitimde Bilgi ve İletişim Teknolojilerini Kullanmaya İlişkin Yeterlilik Algıları Ölçeğinden $(r(206)=0.62, p<.05)$ alınan puanlar arasında pozitif yönde istatistiksel olarak anlamlı ilişkiler bulunurken Gerçeklik Şoku Beklentisi Ölçeği'nden $(r(206)=0.06, p>.05)$ alınan puanlar arasında 
istatistiksel olarak anlamlı ilişki saptanmamıştır. Sonuç olarak, uyarlaması gerçekleştirilen ölçek boyutları ile Genel Bit Eğilimi ölçeğinden elde edilen puanlar arasında saptanan istatistiksel olarak anlamlı korelasyon, ölçeğin yakınsak geçerliğe; Gerçeklik Şoku Beklentisi ölçeğinden elde edilen puanlar ile istatistiksel olarak anlamlı korelasyon bulunmaması ölçeğin ayırt edici geçerliğe; ve BİT Yeterlik Algıları ölçeğinden elde edilen puanlar ile istatistiksel olarak anlamlı korelasyon bulunması ölçeğin eş zamanlı geçerliğe sahip olduğunu göstermektedir (Tablo 3).

Tablo 3. Ölçeklerden Alınan Puanlar arasındaki Korelasyon Katsayıları

\begin{tabular}{lccccc}
\hline Ölçekler & $\mathbf{1}$ & $\mathbf{2}$ & $\mathbf{3}$ & $\mathbf{4}$ & $\mathbf{5}$ \\
\hline 1. Öğrencilerin BİT Kullanımlarını Destekleme Konusunda & 1.00 & & & & \\
BİT Yeterlikleri & & & & & \\
2. Öğretim Tasarımına Yönelik BİT Yeterlikleri & $.68^{*}$ & 1.00 & & & \\
3. Genel BİT Eğilimi & $.51^{*}$ & $.56^{*}$ & 1.00 & & \\
4. BİT Yeterlik Algıları & $.48^{*}$ & $.62^{*}$ & $.48^{*}$ & 1.00 & \\
5. Gerçeklik Şoku Beklentisi & .11 & .06 & .12 & .09 & 1.00 \\
\hline$* p<.05$ & & & & &
\end{tabular}

\section{Güvenirlik Analizine İlişkin Bulgular}

Öğretmen Adayları için BİT Yeterlikleri Ölçeğinin güvenirliği ölçek alt boyutları için hesaplanan Cronbach alfa iç tutarlılık katsayısı ile incelenmiştir. Araştırmada 206 katılımcıdan elde edilen verilerin Cronbach alfa iç tutarlılık katsayıları Öğrencilerin BİT Kullanımlarını Destekleme Konusunda BİT Yeterlikleri ve Öğretim Tasarımına Yönelik BİT Yeterlikleri boyutları için sırasıyla .91 ve .82 olarak hesaplanmıştır. Güvenirlik katsayısı .70 ve üzerinde olan verilerin güvenilir olduğu kabul edilmektedir (Kline, 2016; Nunnaly, 1978). Buna göre, Öğretmen Adayları için BİT Yeterlikleri Ölçeğinin Türkçe formundan elde edilen verilere ait puan güvenilirliğinin yüksek olduğu görülmüştür.

\section{Tartışma ve Sonuç}

Standardize edilmiş ve geçerliği kanıtlanmış veri toplama araçlarının kullanılması konusunda alanyazında kayda değer bir vurgu bulunmaktadır (Gjersing, Caplehorn, \& Clausen, 2010). Bu durumun sebeplerinden biri, uyarlanmış ölçeklerin ulusal ve uluslararası farklı çalışmaların sonuçlarını karşılaştırmayı mümkün kılmasıdır (Van Widenfelt, Treffers, de Beurs, Siebelink, \& Koudijs, 2005; Laake, Olsen, \& Benestad, 2007). Ayrıca uyarlanmış ölçeklerin kullanılması, ölçülmek istenen özelliğin ölçek tarafından ölçülüp ölçülmediğine ilişkin geçerliği de artırır (Laake, Olsen, \& Benestad, 2007). Bu doğrultuda araştırmacıların uluslararası karşılaştırmalar yapabilecekleri çalışmalarda kullanabilmeleri niyetiyle, bu çalışmada Tondeur ve meslektaşları (2017) tarafından geliştirilmiş olan Öğretmen Adayları için BİT Yeterlikleri Ölçeğinin Türk dili ve kültürüne uyarlanması amaçlanmıştır. Bu amaç doğrultusunda öğretmen adaylarından toplanan veriler üzerinde geçerlik ve güvenirlik çalışmaları yürütülmüştür.

Öncelikle Tondeur ve meslektaşları (2017) tarafından geliştirilen Öğretmen Adayları için BİT Yeterlikleri Ölçeği iki boyut ve 19 maddeden oluşmaktadır. Ölçeğin geliştirilme aşamasında 20'nin üzerinde öğretmen ve öğretmen adayları için BİT yeterlik çerçevesi incelenmiş ve bu yapılar kuramsal temel alınarak ölçek maddeleri ortaya oluşturulmuştur. Ulusal alanyazında Şad ve Nalçacı (2015) ile Şimşek ve Yazar (2016) tarafından geliştirilen ölçekler de BİT yeterliklerini ölçmeyi amaçlamaktadır. Bu ölçekler sırasıyla 30 ve 40 maddeden oluşmaktadır. Sözü edilen ölçekler tek bir kuramsal temel baz alınarak geliştirilmiştir. Bu bağlamda bu çalışmada uyarlaması gerçekleştirilen ölçeğin daha kapsayıcı bir kuramsal temele sahip olduğu söylenebilir. Ayrıca ölçeğin daha kısa olması, bir avantaj olarak ortaya çıkmaktadır.

Türkçe formun orijinal form ile dilsel eşdeğerliği, uzman görüşleri doğrultusunda sağlanmıştır. Ölçeğin yapı geçerliğini sınamak amacıyla öncelikle doğrulayıcı faktör analizi gerçekleştirilmiştir. Doğrulayıcı faktör analizi sonucunda uyarlama çalışması yapılan Türkçe formun, özgün ölçekle aynı şekilde 2 faktörlü yapıyı sağladığı belirlenmiştir. Uyum indeksleri incelendiğinde, özgün form ve Türkçe formdan elde edilen değerlerin birbirine yakın olduğu gözlemlenmiştir. Yakınsak geçerlik için Türkçe form ile Günbatar (2015) tarafından geliştirilen Bilgi ve İletişim Teknolojilerine Yönelik Tutum Ölçeğinin Genel BİT Eğilim alt ölçeği arasındaki korelasyon incelenmiştir. Kuramsal olarak ilişkili olması beklenen bu iki ölçek arasında 
istatistiksel olarak anlamlı ve olumlu yönde bir ilişki saptanmıştır. Ayırt edici geçerlik için ise Türkçe form ile Kim ve Cho (2014) tarafindan geliştirilen ve Özdemir ve Büyükgöze (2016) tarafından Türkçeye uyarlanan Gerçeklik Şoku Beklentisi Ölçeğinden elde edilen veriler arasındaki korelasyon incelenmiştir. Analiz sonucunda kuramsal olarak birbiri ile ilişkili olması beklenmeyen bu ölçekler arasında istatistiksel olarak anlamlı ilişki saptanmamıştır. Ölçeğin eşzamanlı geçerliğini sınamak amacıyla Şad ve Nalçacı (2015) tarafindan geliştirilen Öğretmen Adaylarının Eğitimde Bilgi ve İletişim Teknolojilerini Kullanmaya İlişkin Yeterlilik Algıları Ölçeğinden alınan puanlar ölçüt olarak kullanılmıştır. Aynı yapıyı ölçen bu iki formdan elde edilen arasındaki korelasyon incelenmiştir. Analiz sonucu bu iki formdan elde edilen puanlar arasında istatistiksel olarak anlamlı ve olumlu yönde bir ilişki saptanmıştır. Bu bulgulardan hareketle Öğretmen Adayları için BİT Yeterlikleri Ölçeği’nin Türkçe formunun yapı, yakınsak, ayırt edici ve eş zamanlı geçerliği sağladığı görülmüştür. Öğretmen Adayları için BİT Yeterlikleri Ölçeğinin güvenirlik analizi, Cronbach alfa iç tutarlılık katsayısı incelenerek gerçekleştirilmiştir. Bu analiz sonuçlarına göre Öğrencilerin BİT Kullanımlarını Destekleme Konusunda BİT Yeterlikleri boyutunun ve Öğretim Tasarımına Yönelik BİT Yeterlikleri boyutunun iç tutarlılık katsayıları sırasıyla .91 ve .82 olarak hesaplanmıştır. Bu bulgular, Tondeur ve diğerlerinin (2017) çalışmasında elde ettiği bulgular tarafindan desteklenmektedir. Bu bulgulara dayanarak, boyutlardan elde edilen puanların yüksek güvenirliğe sahip olduğu sonucuna varılmıştır. Araştırma sonucunda geçerlik ve güvenirliğe ilişkin elde edilen bulgular, Türkçeye uyarlanan Öğretmen Adayları için BİT Yeterlikleri Ölçeğinin öğretmen adaylarının bilgi ve iletişim teknolojileri yeterlik düzeylerini belirlemede uygun bir araç olduğunu ortaya koymuştur. Sonuç olarak Türk kültürü ve diline uyarlaması gerçekleştirilen Öğretmen Adayları için BİT Yeterlikleri Ölçeğinin yeterli psikometrik özelliklere sahip bir ölçme aracı olduğu söylenebilir.

Gelecekte yapılacak araştırmaların uyarlaması gerçekleştirilen ölçeği farklı örneklemlere uygulayarak ve geçerlik ve güvenirlik analizlerini tekrarlayarak bu konuda daha fazla delil ortaya konması önerilmektedir. Ayrıca gelecekteki çalışmalarda ölçeğin farklı alanlarda eğitim alan kadın-erkek ve/veya farklı sınıf seviyelerindeki öğretmen adayları için Öğretmen Adayları için BİT Yeterlikleri Ölçeğinin ölçme değişmezliği durumu incelenmelidir.

Günümüz eğitim ortamlarının gelişmekte olduğu yön göz önünde bulundurulduğunda, öğretmenlerin bilgi ve iletişim teknolojilerini etkili kullanma becerilerinin önemi daha fazla ortaya çıkmaktadır. Bu tür becerilerin öğretmen yetiştiren kurumlar tarafından eğitimleri sırasında öğretmen adaylarına kazandırılmasının, adayların öğretmenliğe başladıktan sonra bilgi ve iletişim teknolojilerine yönelik muhtemel sorunlarının önüne geçilmesine katkı sağlayacağı düşünülmektedir. Bu açıdan bakıldığında, öğretmen adaylarına ihtiyaç duydukları eğitimin verilebilmesi için öncelikle bilgi ve iletişim teknolojileri yeterliklerine ne ölçüde sahip olduklarının belirlenmesi gerekmektedir. Diğer bir deyişle, öğretmenlere yönelik hizmet öncesi eğitimin planlanması, geliştirilmesinde ve değerlendirilmesinde, öğretmen adaylarının yeterliklerinin ortaya çıkarılması son derece önemlidir. Bu sayede, öğretim süreçleri öğretmen adaylarının ihtiyaçlarını karşılamaya yönelik olarak tasarlanabilir ve gerçekleştirilen öğretim süreçlerinin etkililiği de öğretmen adaylarının yeterlikleri sağlama düzeyleri incelenerek değerlendirilebilir.

\section{Bilgilendirme}

Bu çalı̧̧manın özeti 27-28 Ekim 2017 tarihlerinde Sivas Cumhuriyet Üniversitesi'nde gerçekleştirilen Uluslararası Eğitim Teknolojileri Sempozyumu'nda bildiri olarak sunulmuştur. Bu çalışmada uyarlaması gerçekleştirilen ölçek Ek 1'de verilmiş̧ir. Araştırmacılar uygun bir şekilde atıfta bulunarak ölçeği kullanabilirler. 


\section{References}

Baumgartner, H., \& Homburg, C. (1996). Applications of structural equation modeling in marketing and consumer research: A review. International Journal of Research in Marketing, 13(2), 139-161.

Baylor, A. L., \& Ritchie, D. (2002). What factors facilitate teacher skill, teacher morale, and perceived student learning in technology-using classroom? Computers \& Education, 39(4), 395-414. doi: 10.1016/S0360-1315(02)00075-1.

Bollen, K. A. (1989). Structural equations with latent variables. New York: Wiley Publications.

Borsa, J. C., Damásio, B. F., \& Bandeira, D. R. (2012). Cross-cultural adaptation and validation of psychological instruments: Some considerations. Paidéia, 22(53), 423-432. doi:10.1590/198243272253201314

Brenner, A., \& Brill, J. (2016). Investigating practices in teacher education that promote and inhibit technology integration transfer in early career teachers. TechTrends, 60(2), 136-144. doi:10.1007/s11528-016-0025-8

Brown, T. A. (2006). Confirmatory factor analysis for applied research. New York: The Guilford Press.

Chan, F.-M. (2002). ICT in Malaysian schools: Policy and strategies. Workshop on the Promotion of ICT in Education to Narrow the Digital Divide, (s. 15-22). Tokyo, Japan.

Dilalla, L. F. (2000). Structural equation modeling: Uses and issues. In H. E. Tinsley, \& S. D. Brown, Handbook of applied multivariate statistics and mathematical modeling (pp. 440-456). San Diego: Academic Press.

European Institute for E-Learning. (2017). The e-learning competency framework for teachers and trainers. Retrieved from http://www.eife-l.org/competencies/ttframework

Ferrari, A. (2013). DIGCOMP: A framework for developing and understanding digital competence in Europe. Spain: European Commission.

Flora, D., LaBrish, C., \& Chalmers, P. (2012). Old and new ideas for data screening and assumption testing for exploratory and confirmatory factor analysis. Frontiers in Psychology, 3, 1-21. doi:10.3389/fpsyg.2012.00055

Fu, J. S. (2013). ICT in education: A critical literature review and its implications. International Journal of Education and Development using Information and Communication Technology, 9(1), 112-125.

Gjersing, L., Caplehorn, J., \& Clausen, T. (2010). Cross-cultural adaptation of research instruments: Language, setting, time and statistical considerations. BMC Medical Research Methodology, 10(13). doi:10.1186/1471-2288-10-13

Godinho, T. (2015). Portugal: Country report on ICT in education. Brussels: European Schoolnet.

Gravetter, F. J., \& Forzano, L. B. (2012). Research methods for the behavioral sciences. USA: Wadsworth Cengage Learning.

Gudmundsson, E. (2009). Guidelines for translating and adapting psychological instruments. Nordic Psychology, 61(2), 29-45. doi:10.1027/1901-2276.61.2.29

Günbatar, M. S. (2014). The study on development of information and communication technology attitude scale. Journal of Kırşehir Education Faculty, 15(1), 121-135.

Hair, J. F., Black, W. C., Babin, B. J., Anderson, R. E., \& Tatham, R. L. (2006). Multivariate data analysis. Upper Saddle River: Pearson Prentice Hall.

Hew, T. S., \& Leong, L. Y. (2011). An empirical analysis of Malaysian pre-university students' ICT competency gender differences. International Journal of Network and Mobile Technologies, 2(1), 1529. 
Hsu, S. (2010). Developing a scale for teacher integration of information and communication technology in grades 1-9. Journal of Computer Assisted Learning, 26(3), 175-189. doi: 10.1111/j.13652729.2010.00348.x

ISTE. (2014). ISTE standards teachers. Retrieved from https://www.iste.org/docs/pdfs/2014_ISTE_Standards-T_PDF.pdf

Kim, H., \& Cho, Y. (2014). Pre-service teachers' motivation, sense of teaching efficacy, and expectation of reality shock. Asia-Pacific Journal of Teacher Education, 42(1), 67-81.

Kline, R. B. (2016). Principles and practice of structural equation modeling (4 ${ }^{\text {th }}$ ed.). New York: Guilford Publications.

Laake, P., Olsen, B. R., \& Benestad, H. B. (2007). Research methodology in the medical and biological sciences. Amsterdam: Elsevier Academic Press.

MacCallum, R. C., Browne, M. W., \& Sugawara, H. M. (1996). Power analysis and determination of sample size for covariance structure modeling. Psychological Methods, 1(2), 130-149.

Mardia, K. V. (1970). Measures of multivariate skewness and kurtosis with applications. Biometrika, 57(3), 519-530.

Markauskaite, L. (2007). Exploring structure of trainee teachers' ICT literacy: the main components of, and relationships between, general cognitive and technical capabilities. Educational Technology Research and Development, 55(6), 547-572. doi: 10.1007/s11423-007-9043-8

Marsh, H. W., Hau, K. T., \& Wen, Z. (2004). In search of golden rules: Comment on hypothesis-testing approaches to setting cutoff values for fit indexes and dangers in overgeneralizing $\mathrm{Hu}$ and Bentler's (1999) findings. Structural Equation Modeling, 11(3), 320-341.

MEB. (2006). Öğretmenlik mesleği genel yeterlikleri [General competencies of teaching profession]. Ankara: Ministry of National Education.

MEB. (2017). About FATIH project. Retrieved from http://fatihprojesi.meb.gov.tr/proje-hakkinda/

Morin, A., Scalas, F., Vispoel, W., Marsh, H., \& Wen, Z. (2016). The music self-perception inventory: Development of a short form. Psychology of Music, 44(5), 915-934. doi:10.1177/0305735615592690

Mumtaz, S. (2000). Factors affecting teachers' use of information and communications technology: a review of the literature. Journal of Information Technology for Teacher Education, 9(3), 319-342. doi:10.1080/14759390000200096

Muthen, L. K., \& Muthen, B. O. (2007). Mplus user's guide. Los Angeles: Muthen \& Muthen.

Nunnaly, J. (1978). Psychometric theory. New York: McGraw-Hill.

Özdemir, M., \& Büyükgöze, H. (2016). The adaptation of reality shock expectation scale and a study on prospective teachers. Journal of Kırşehir Education Faculty, 17(2), 243-257.

Shen, S., Schüttemeyer, A., \& Braun, B. (2009). Visitors' intention to visit world cultural heritage sites: An empirical study of Suzhou, China. Journal of Travel \& Tourism Marketing, 26(7), 722-734. doi:10.1080/10548400903284610

Suarez-Rodríguez, J. M., Almerich, G., Díaz-García, I., \& Fernandez-Piqueras, R. (2012). ICT Competences of teachers. Influence of personal and contextual factors. Univ. Psychol, 11(1), 293-309.

Şad, S. N., \& Nalçacı, Ö. İ. (2015). Prospective teachers' perceived competencies about integrating information and communication technologies into education. Mersin University Journal of the Faculty of Education, 11(1), 177-197.

Şimşek, Ö., \& Yazar, T. (2016). Education Technology Standards Self-Efficacy (ETSSE) Scale: A Validity and Reliability Study. Eurasian Journal of Educational Research, 63, 311-334.

Tabachnick, B., \& Fidell, L. (2013). Using multivariate statistics (6 ${ }^{\text {th }}$ ed.). Boston: Pearson. 
Tasir, Z., Abour, K. M., Halim, N. D., \& Harun, J. (2012). Relationship between teachers' ICT competency, confidence level, and satisfaction toward ICT training programmes: A case study among postgraduate students. The Turkish Online Journal of Educational Technology, 11(1), 138-144.

Tondeur, J., Aesaert, K., Pynoo, B., Braak, J. v., Fraeyman, N., \& Erstad, O. (2017). Developing a validated instrument to measure preservice teachers' ICT competencies: Meeting the demands of the 21 st century. British Journal of Educational Technology, 48(2), 462-472. doi:10.1111/bjet.12380

UNESCO. (2008). ICT competency standards for teachers. United Kingdom: UNESCO. Retrieved from http://unesdoc.unesco.org/images/0015/001562/156210E.pdf

Van Widenfelt, B. G., Treffers, P. D. A., de Beurs, E., Siebelink, B. M., \& Koudijs, E. (2005). Translation and cross-cultural adaptation of assessment instruments used in psychological research with children and families. Clinical Child and Family Psychology Review, 8(2), 135-147. Doi: 10.1007/s10567-005$4752-1$

Virginia Technology Standards for Instructional Personnel. (1998). Retrieved from http://www.educate.vt.edu/teeps/vastandards.htm

Wolf, E. J., Harrington, K. M., Clark, S. L., \& Miller, M. W. (2013). Sample size requirements for structural equation models: An evaluation of power, bias, and solution propriety. Educational and Psychological Measurement, 73(6), 913-934. doi: 10.1177/0013164413495237 
Appendix 1. The Original and Turkish Version of Preservice Teachers' Information and Communication Technology Competencies Scale

Please circle the number on the scale that most accurately reflects your response to each item.

\begin{tabular}{ccc}
1 & 2 & 3 \\
Strongly & Disagree & $\begin{array}{l}\text { Neither Agre } \\
\text { Nor Disagre }\end{array}$ \\
\hline
\end{tabular}

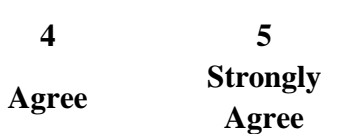

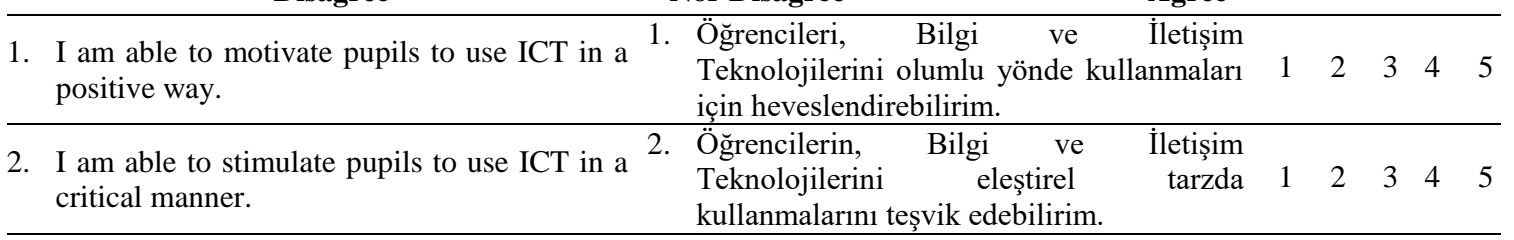

3. I am able to provide pupils with activities to 3. Öğrencilere, Bilgi ve İletişim Teknolojileri exercise knowledge/skills by means of ICT. aracılığıla bilgi / beceri alıştırmaları $1120 \begin{array}{lllll} & 2 & 4 & 5\end{array}$ yapacakları etkinlikler sağlayabilirim.

4. I am able to provide pupils with activities on

4. Öğrencilere, ders konularını Bilgi ve İletişim Teknolojileri ile öğrenebilecekleri $1 \begin{array}{lllll}1 & 2 & 3 & 4 & 5\end{array}$ subject matters to learn with ICT. etkinlikler sağlayabilirim.

5. I am able to offer pupils opportunities to 5. Öğrencilere, Bilgi ve İletişim Teknolojileri express ideas in a creative way by means of aracılığıla fikirlerini yaratıcı bir biçimde ICT. ifade edebilecekleri imkânlar sunabilirim.

6. I am able to support pupils in searching 6. Öğrencileri, Bilgi ve İletişim Teknolojileri information by means of ICT.

aracılığıla bilgi arama konusunda destekleyebilirim.

7. I am able to support pupils in processing and 7. Öğrencileri, Bilgi ve İletişim Teknolojileri managing information by means of ICT. yoluyla bilgi işleme ve yönetme konusunda destekleyebilirim.

8. I am able to support pupils to present information by means of ICT.

8. Öğrencilerin Bilgi ve İletişim Teknolojileri

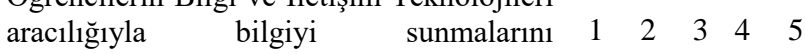
destekleyebilirim. 9. I am able to support pupils to communicate $\begin{aligned} & \text { 9. Öğrencilerin } \\ & \text { Teknolojileriyle güvenli, }\end{aligned}$ verumlu ve etkilisi with ICT in a safe, responsible and effective way. bir şekilde iletişim kurmalarını destekleyebilirim.

10. I am able to support pupils to work together 10. Öğrencileri, Bilgi ve İletişim Teknolojileri with ICT.

$\begin{array}{lllllll}\text { kullanarak birlikte çalışmaları konusunda } & 1 & 2 & 3 & 4 & 5\end{array}$ destekleyebilirim.

11. I am able to educate pupils to use ICT in a

11. Öğrencileri, bilinçli bir şekilde Bilgi ve conscious way (respecting ergonomics, intellectual property, etc). İletişim Teknolojilerini kullanma konusunda eğitebilirim (ergonomi, fikri $110 \begin{array}{lllll}2 & 2 & 4 & 5\end{array}$ mülkiyet, vb. konulara sayg1 duymaları konusunda).

12. I am able to select ICT applications in view of a specific educational setting.

12. Belirli bir eğitim ortamını dikkate alarak,

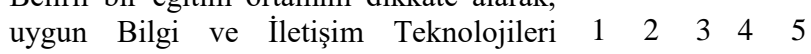
uygulamalarını seçebilirim.

13. I am able to (re)design ICT applications in 13. Belirli bir eğitim ortamını dikkate alarak, $\begin{array}{ll}\text { view of a specific educational setting. } & \begin{array}{l}\text { Bilgi ve İletişim Teknolojile } \\ \text { uygulamalarını (yeniden) tasarlayabilirim. }\end{array}\end{array}$

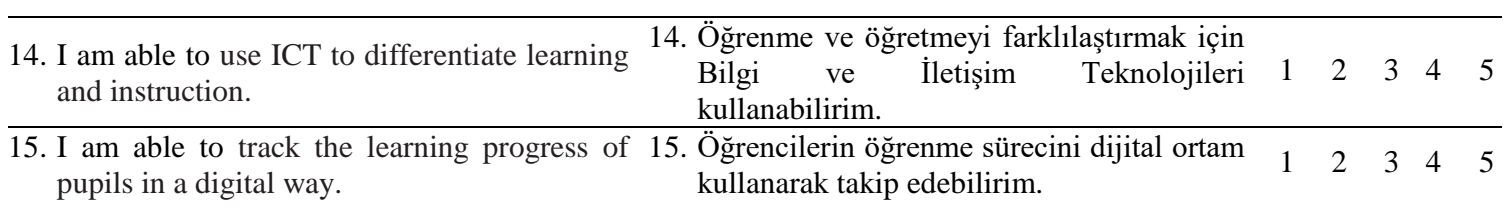




\section{Appendix 1 Continuation}

16. I am able to evaluate pupils with the help of 16 . Bilgi ve İletişim Teknolojileri yardımıla $1 \quad 2 \quad 3 \quad 4 \quad 5$ ICT. öğrencileri değerlendirebilirim.

17. I am able to use ICT appropriately to 17. Öğrencilerle iletişim kurmak için Bilgi ve communicate with pupils. İletişim Teknolojilerini uygun bir şekilde $\begin{array}{lllll}1 & 2 & 3 & 4 & 5\end{array}$ kullanabilirim.

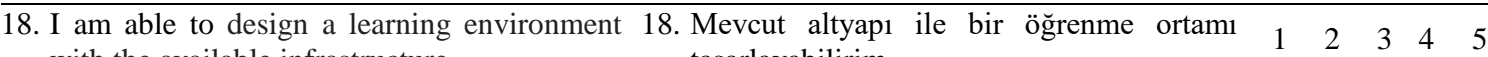
with the available infrastructure. tasarlayabilirim.

19. I am able to select ICT applications 19. Bir öğrenme ortamı oluştururken Bilgi ve (eg, in view of the group size). bir şekilde seçebilirim (örn. grup boyutu göz önüne alındığında).

Items 1-11: ICT competencies to support pupils for ICT use (ICTC-PU)

Items 12-19: ICT competencies for instructional design (ICTC-ID) 